\title{
AURICULAR PAROXYSMAL TACHYCARDIA WITH AURICULOVENTRICULAR BLOCK
}

\author{
Paul S. Barker, M.D., Frank . N. Wilson, M.D., \\ Frantilin D. Johnston, M.D., Ann Arbor, Mich., and \\ Sheldy W. Wishart, M.D., Evansville, Ind.
}

\begin{abstract}
A URICULAR paroxysmal tachycardia is a condition in which the heart beats rapidly and regularly in response to impulses arising in the auricles. The attacks are characterized by abrupt transitions, from normal rhythm to tachyeardia at their onset, and from tachycardia to normal rhythm at their termination. They usually last a few minutes or a few hours, rarely much longer. The rate is usually between 150 and 220 per minute, commonly near 200. The ventricles respond, as a rule, to each auricular beat. The attacks ean often be stopped by pressure upon the carotid sinus, or by large doses of digitalis, less commonly by quinidine. The precise mechanism of the auricular tachycardia is not understood. It is commonly believed that a rapid succession of impulses arises from an ectopic focus in the auricles. It is possible that in some manner each beat initiates the succeeding beat, or that the tachycardia depends upon the establishment of a circus rhythm in the auricular musele. This last possibility has been diseussed in considerable detail by Lewis. ${ }^{1}$ It is of interest that auricular paroxysmal tachycardia seldom occurs in patients who have had previous attacks of auricular flutter or fibrillation, and that these disturbances, which are caused by eireus rhythm, are nucommon in patients who have had aurieular paroxysmal tachyeardia.

In anricular flutter the auricular activity is characterized by a high degree of regularity and uniformity. The aurieular rate is usually between 240 and 375 per minute. The ventrieles very rarely respond to each auricular impulse; there is nearly always partial atrioventricular block, commonly $2: 1$. The ahnormal mechanism is usually more persistent than auricular paroxysmal tachycardia, and often lasts for weeks or months, but repeated short attacks sometimes occur. Carotid sinus pressure slows the ventricles but does not alter the auricular mechanism. Digitalis slows the ventricles, and, when large amounts are given, usually converts auricular flutter into auricular fibrillation. Quinidine always slows the auricular rate, but does not often restore normal rhythm.

In rare instances of auricular paroxysmal tachyeardia, the ventricles do not respond to each auricular beat in the usual manner. There may

From the Department of Internal Medicine, University of Michigan MedicaI School and the University Hospital. Read in part before the Central Society for Clinical Research, Chicago, Nov, 4,

The collection of the material upon which this paper is based was aided by a grant to $F$. N. Wilson from the Horace $H$. Rackham School of Graduate Studies.

Received for publication Aug. 4, 1942.
\end{abstract}


['ABST:

Auriguiar Paroxysmat Tachyoahdi

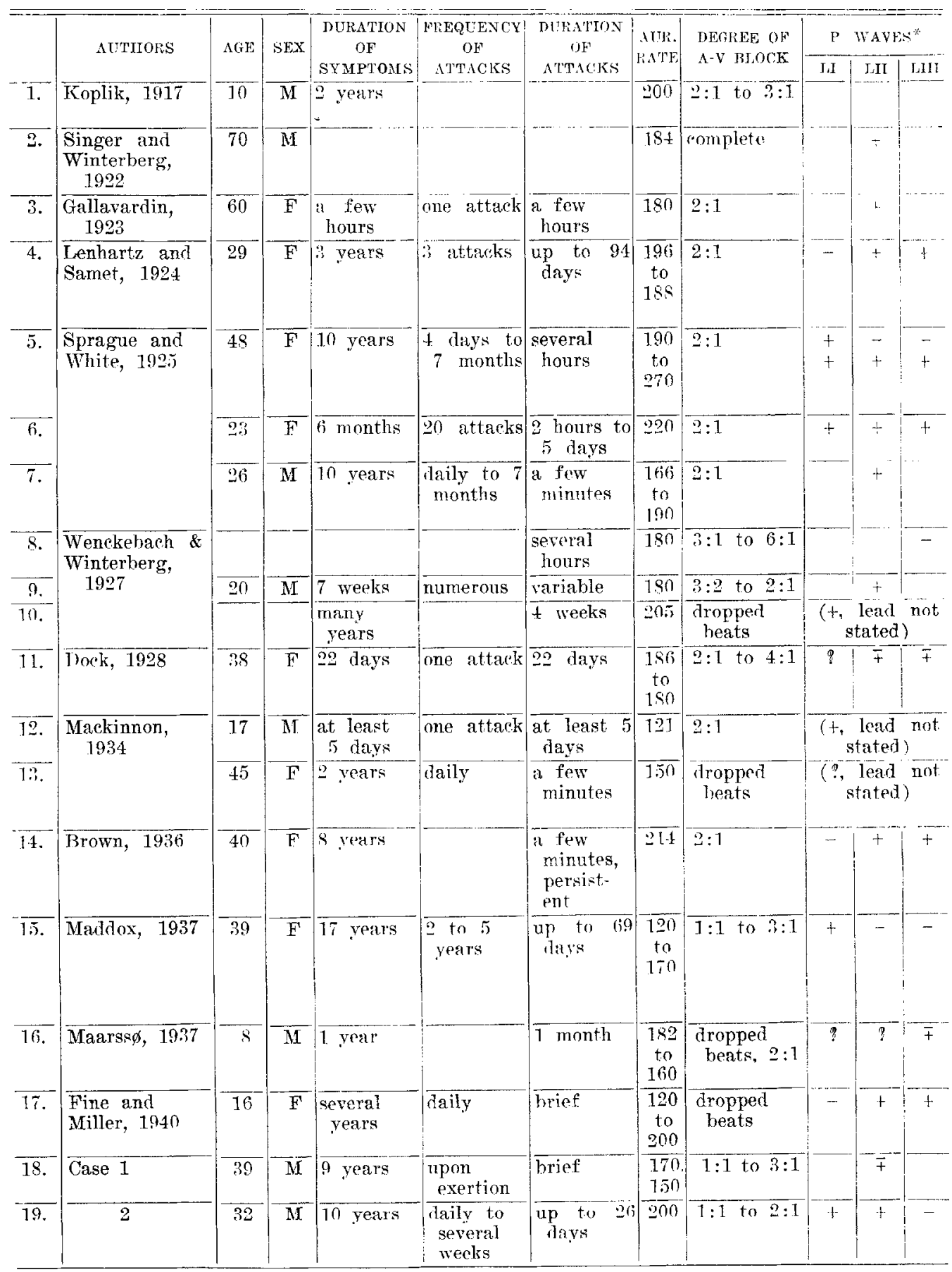

*During paroxysmal tachycardia. +, upright; -. inverted: \pm , cliphasic, upward and then downward; $\bar{F}$, diphasic, downward and then upward;? not visible. 
I

WITH Auriculoventricular Block

\begin{tabular}{|c|c|c|c|c|c|c|}
\hline $\begin{array}{c}\text { DIS- } \\
\text { ABILITY }\end{array}$ & $\begin{array}{c}\text { CONGES- } \\
\text { TIVE } \\
\text { FAILURE } \\
\end{array}$ & $\begin{array}{l}\text { ORGANIC } \\
\text { HEART } \\
\text { DISEASE }\end{array}$ & $\begin{array}{c}\text { NEEFFEC- } \\
\text { TIVE } \\
\text { TREATMENT }\end{array}$ & $\begin{array}{r}\text { EFFECTIVE } \\
\text { TREATMENT }\end{array}$ & RESULT & REMARKS \\
\hline \multirow[t]{3}{*}{ moderate } & none & none & & & & $\begin{array}{l}\text { nectrocardiograms } \\
\text { not published }\end{array}$ \\
\hline & & & & quinine & $\begin{array}{l}\text { stopped the } \\
\text { paroxysm }\end{array}$ & \\
\hline & & $\begin{array}{r}\text { syphilitic } \\
\text { aortitis }\end{array}$ & & & normal rliythm & \\
\hline marked & none & none & quinine & $\begin{array}{l}\text { digitalis } \\
\text { and phy- } \\
\text { sostig- } \\
\text { mine }\end{array}$ & normal rhythm & $\begin{array}{l}\text { aur. rate slowed by } \\
\text { quinine and by digi } \\
\text { talis and physostig- } \\
\text { mine }\end{array}$ \\
\hline moderate & none & none & quinidine & $\begin{array}{l}\text { digitalis, } \\
\text { removal } \\
\text { of cervi- } \\
\text { cal ribs }\end{array}$ & normal rhythm & \\
\hline moderate & none & none & quinidine & $\begin{array}{l}\text { digitalis, } \\
\text { rest }\end{array}$ & normal rhythm & \\
\hline \multirow[t]{4}{*}{ slight } & none & none & quinidine & digitalis & normal rhythm & \\
\hline & & & & quinine & normal rhythm & \\
\hline & & none & & & normal rhythm & \\
\hline & & & & quinine & normal rhythm & \\
\hline marked & present & mitral stenosis & digitalis & & $\begin{array}{l}\text { A-V brady- } \\
\text { cardia }\end{array}$ & \\
\hline marked & yresent & $\begin{array}{l}\text { mitral stenosis, } \\
\text { aortic regurg. }\end{array}$ & & digitalis & $\begin{array}{r}\text { increased block, } \\
\text { normal rliythm }\end{array}$ & \\
\hline slight & none & initral lesion & & $\begin{array}{l}\text { carotid } \\
\text { sinus } \\
\text { pressure }\end{array}$ & normal rhythm & $\begin{array}{l}\text { probable case. P not } \\
\text { identified }\end{array}$ \\
\hline marked & $\begin{array}{l}\text { acute } \\
\text { edema } \\
\text { of } \\
\text { lungs }\end{array}$ & $\begin{array}{l}\text { mitral and pul- } \\
\text { monary lesions or } \\
\text { congenital heart }\end{array}$ & & digitalis & normal rhythm & $\begin{array}{l}\text { changed to aur. fibr. } \\
\text { and then to normal } \\
\text { rhythm after digi- } \\
\text { talis }\end{array}$ \\
\hline moderate & none & none & $\begin{array}{l}\text { quinine } \\
\text { quinidine } \\
\text { digitalis } \\
\text { acetylelo- } \\
\text { line }\end{array}$ & rest & normal rhythm & $\begin{array}{l}\text { sinus tachycardia } \\
\text { influenced by rest, } \\
\text { exercise, emotion, } \\
\text { sleep; auricular rate } \\
\text { slowed by digitalis }\end{array}$ \\
\hline present & none & enlargement & digitalis & & & \\
\hline moderate & none & none & $\begin{array}{l}\text { carotid } \\
\text { sinus } \\
\text { pressure }\end{array}$ & $\begin{array}{c}\text { digitalis, } \\
\text { quinidine }\end{array}$ & normal rhythm & $\begin{array}{l}\text { rate influenced by } \\
\text { posture }\end{array}$ \\
\hline slight & none & none & quinidine & digitalis & $\begin{array}{l}\text { increased de- } \\
\text { gree of bloek }\end{array}$ & normal rhythm later \\
\hline miraked & none & mitral stenosis & $\begin{array}{l}\text { quinidine } \\
\text { quinine } \\
\text { mecholyl }\end{array}$ & $\begin{array}{l}\text { digitalis, } \\
\text { rest }\end{array}$ & $\begin{array}{l}\text { increased de- } \\
\text { gree of block, } \\
\text { improved }\end{array}$ & $\begin{array}{l}\text { also auricular flutter } \\
\text { and fibrillation }\end{array}$ \\
\hline
\end{tabular}


${ }^{i} 1 \mathrm{x}, \mathrm{B} \mid \mathrm{k}$

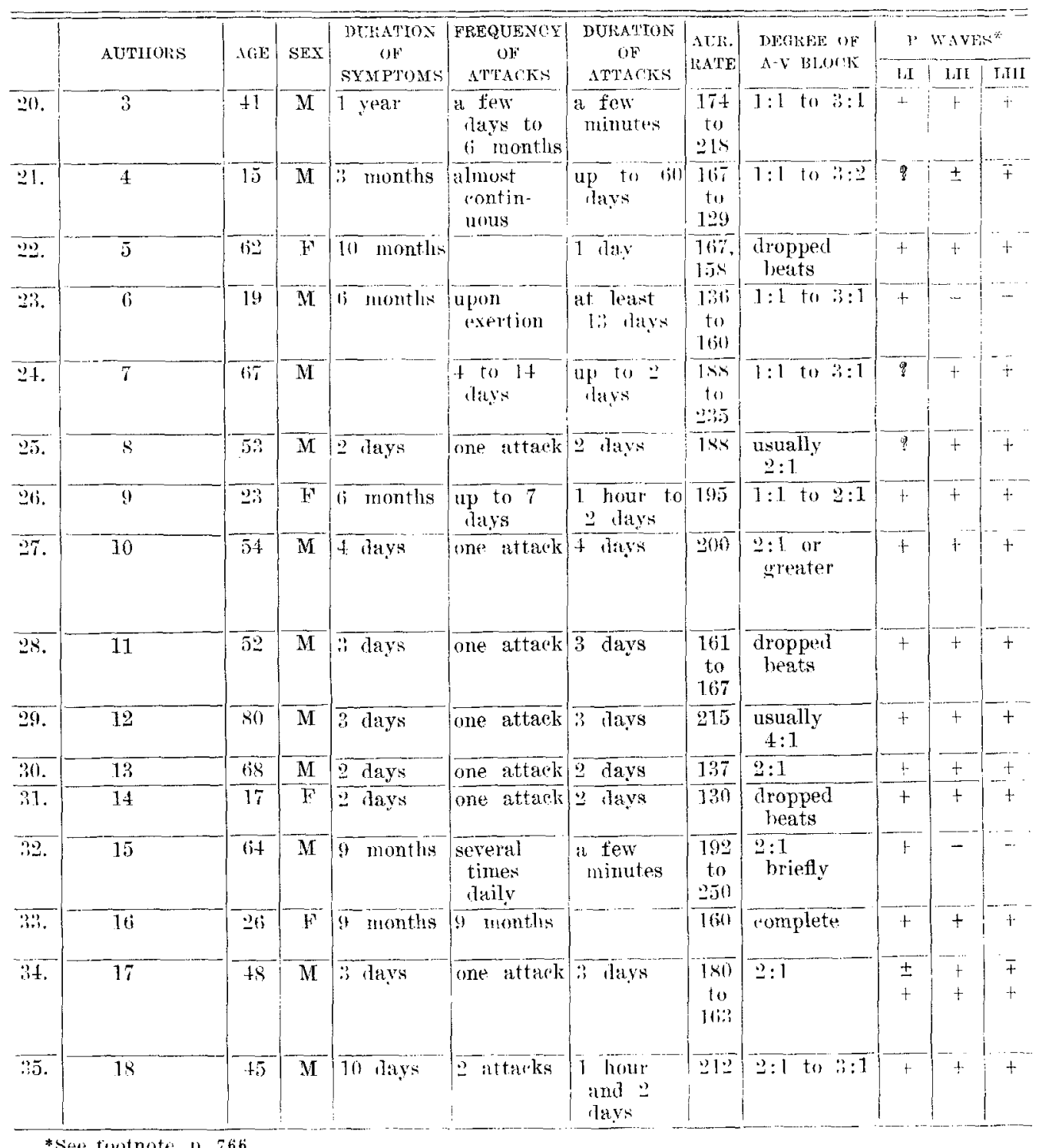

be oceasional dropped ventrieular beats, or $2: 1$ or higher grades of auriculoventricular block. Auricular paroxysmal tachycardia associated with heartblock differs in several important respects from ordinary paroxysmal tachycardia of auricular origin, and resembles auricular flutter in some particulars. The purpose of this paper is to review seventeen previously reported cascs, to present eighteen additional cases, and to describe some of their peculiarities. The important features of these thirty-five cases have been tabulated (Table I). 
I-CONT'D

\begin{tabular}{|c|c|c|c|c|c|c|}
\hline $\begin{array}{c}\text { DIS- } \\
\text { ABILITY }\end{array}$ & $\begin{array}{l}\text { CONGES- } \\
\text { TIVE } \\
\text { FAILURE } \\
\end{array}$ & $\begin{array}{l}\text { ORGANIC } \\
\text { HEART } \\
\text { DISEASE }\end{array}$ & \begin{tabular}{|c|} 
INEFFEC- \\
TIVE \\
TREATMENT \\
\end{tabular} & $\begin{array}{c}\text { EFFECTIVE } \\
\text { TREATMENT }\end{array}$ & l:ESULT & REMARKS \\
\hline $\begin{array}{l}\text { moderate } \\
\text { to } \\
\text { marked } \\
\end{array}$ & none & none & $\begin{array}{l}\text { quinidine } \\
\text { mecholyl }\end{array}$ & digitalis & $\begin{array}{l}\text { increased de- } \\
\text { gree of block }\end{array}$ & $\begin{array}{l}\text { normal rhythm later, } \\
\text { aur. rate slowed by } \\
\text { quinidine }\end{array}$ \\
\hline marked & present & none & $\begin{array}{l}\text { quinidine } \\
\text { digitalis }\end{array}$ & none & $\left\{\begin{array}{c}\text { died } 84 \text { days } \\
\text { after onset }\end{array}\right.$ & $\begin{array}{l}\text { aur. rate slowed by } \\
\text { guinidine. Autopsy }\end{array}$ \\
\hline slight & none & none & & digitalis & normal rhythm & \\
\hline $\begin{array}{l}\text { moderate } \\
\text { to } \\
\text { marked }\end{array}$ & none & \% mitral lesion & $\begin{array}{l}\text { digitalis } \\
\text { mecholyl }\end{array}$ & quinidine & $\begin{array}{l}\text { normat rhythm; } \\
\text { died suddenly }\end{array}$ & $\begin{array}{l}\text { aur. rate slowed by } \\
\text { quinidine. Autopsy }\end{array}$ \\
\hline moderate & none & $\begin{array}{l}\text { hypertension, } \\
\text { arterioselerosis, } \\
\text { emphysema }\end{array}$ & digitalis & quinidine & normal rhythm & \\
\hline $\begin{array}{l}\text { inci- } \\
\text { dental } \\
\end{array}$ & present & $\begin{array}{l}\text { right-sided } \\
\text { enlargement }\end{array}$ & digitalis & & Aied & $\begin{array}{l}\text { Autopsy; } \\
\text { bronchiectasis }\end{array}$ \\
\hline moderate & none & $\begin{array}{l}\text { mitral stenosis, } \\
\text { aortic regurg. }\end{array}$ & digitalis & quinidine & normal rhythm & \\
\hline slight & none & $\begin{array}{l}\text { hypertension, } \\
\text { slight enlarge- } \\
\text { ment }\end{array}$ & \begin{tabular}{|} 
digitalis \\
(overdigi- \\
talized)
\end{tabular} & $\begin{array}{l}\text { stopped } \\
\text { digitalis }\end{array}$ & normal rhytlim & $\begin{array}{l}\text { changed to aur. flbr. } \\
\text { and then to normal } \\
\text { rhythm. }\end{array}$ \\
\hline marked & present & $\begin{array}{r}\text { hypertension, } \\
\text { enlargement }\end{array}$ & & digitalis & normal rlyythm & $\begin{array}{l}\text { dereloped acute edena } \\
\text { of lungs }\end{array}$ \\
\hline $\begin{array}{l}\text { inci- } \\
\text { dental }\end{array}$ & none & arterioselerosis & digitalis & & & $\begin{array}{l}\text { changed to auricular } \\
\text { fibrillation }\end{array}$ \\
\hline none & $\overline{\text { none }}$ & arteriosclerosis & & & normal rhythm & \\
\hline none & none & $\begin{array}{l}\text { exophthalmie } \\
\text { goitre }\end{array}$ & & & normal rhytlm & \\
\hline slight & none & $\begin{array}{l}\text { arteriosclerosis, } \\
\text { slight enlarge- } \\
\text { ment }\end{array}$ & quinidine & rigitalis & normal rhyt $] \mathrm{mm}$ & $A \cdot V$ block very brief \\
\hline marked & present & $\begin{array}{l}\text { hypertension, } \\
\text { enlargement }\end{array}$ & & digitalis & normal rhythm & \\
\hline $\begin{array}{l}\text { inci- } \\
\text { dental }\end{array}$ & $\begin{array}{l}\text { edema } \\
\text { of } \\
\text { lungs }\end{array}$ & $\begin{array}{l}\text { acute myocardial } \\
\text { infarction, } \\
\text { liypertension, } \\
\text { enlargement }\end{array}$ & digitalis & & nornal rhythın & P waves vary in form \\
\hline $\begin{array}{l}\text { inci- } \\
\text { dental }\end{array}$ & present & $\begin{array}{l}\text { old myocardial in- } \\
\text { farction }\end{array}$ & digitalis & & normal rhythm & \\
\hline
\end{tabular}

\section{PREVIOUSINY RLPORTED CASES}

The first report of auricular paroxysmal tachyeardia with partial A-V block was by Koplik, ${ }^{2}$ in 1917 . The patient was a 10-year-old boy. Many electrocardiograms were obtained, but none were published. In 1922, Singer and Winterberg ${ }^{3}$ published curves from a 70-year-old man whose $A-V$ block was complete, with a ventricular rate of 26 per minute. The auricular paroxysmal tachycardia was stopped by quinine given intravenously. Gallavardin, ${ }^{4}$ in 1923 , described a case in which there were frequent dropped ventrieular beats and short periods of $2: 1 \mathrm{~A}-\mathrm{V}$ 
block interspersed with short runs of $1: 1$ response. He pointed out that such a disturbance could give rise to almost complete irregularity of the ventricles at a rapid rate, closely resembling auricular fibrillation clinically. In 1924, Lenhartz and Samet. reported a case in a 29-year-old nurse who for a long time was thought to have aurieular fibrillation. Normal rhythm was finally restored by the combined use of physostigmine and digitalis after the attack had lasted ninety-four days. Sprague and White, ${ }^{6}$ in 1925 , reported three cases, and briefly compared and contrasted them with auricular flutter. They pointed out that the attacks occurred over a period of years, often lasted several days, and were not influenced favorahly by quinidine, but rould often ho stopped by digitalis in full doses. In 1927, Wenckebach and Winterberg ${ }^{7}$ reported three cases, in two of which normal rhythm was restored by quinine. Dock, ${ }^{8}$ in 1928 , described a case in which the aurjeular paroxysmal tachycardia lasted for twenty-two days and was accompanied by partial A-V block varying in degree from $2: 1$ to $4: 1$, and was not affected appreciably by pressure upon the carotid simus or the cyes or hy large amounts of digitalis. In 1934, Mackimnon reported two cases. One of these was clearly an instance of auricular paroxymal tachycardia with partial $\Lambda-V$ block. The other was similar in most important respects, but can be considered only as a probable case because the auricular waves could not be identified in the records. The author pointed out that in occasional cases of auricular paroxysmal tachycardia the ventricular rhythm may be irregular, and that the usual cause for this irregularity is defective conduction in the $\mathrm{A}-\mathrm{V}$ bundle.

Brown, ${ }^{10}$ in 1936, presented esophageal leads of two patients, which he interpreted as showing auricular paroxysmal tachycardia with partial A-V block. The first of these curves is susceptible of an alternative interpretation, namely, that, while the rate was rapid, the rentricular complexes were slightly aberrant and thus gave the eurve an appearance which somewhat resembled auricular paroxysmal tachycardia with partial A-V block. The second case, however, is clearly a very interesting example of the condition nuder discussion, and illustrates the value of digitalis in its treatment. The author called attention to the differences between auricular paroxysmal tachycardia and auricular flutter as shown by esophageal ]eads. In the former the auricular deflections are separated one from another by intervals during which the tracing remains at the isoelectric level. In flutter, however, the auricular activity produces a continuous ascillation of the tracing, with no isoclectric intervals, suggesting continuous excitation.

In 1937, Maddox ${ }^{11}$ reported a case of auricular paroxysmal tachycardia with variable $\mathrm{A}-\mathrm{V}$ conduction and periods of $2: 1$ or $3: 1$ block. His discussion deals mainly with the site of impulse formation and the influence of the extrinsie eardiae nerves. Maarss $\phi{ }^{12}$ in 1937, reported a case in which an attack of auricular paroxysmal tachycardia lasted longer than one month. At times there was partial A-V block, varying 
in degree from frequent dropped beats to 2:1 response. Fine and Miller, ${ }^{13}$ in 1940 , reported a remarkable case of orthostatic auricular paroxysmal tachycardia in which the rate was influenced by posture. Sometimes the paroxysmal tachycardia was present while the patient was recumbent, and was then sometimes accompanied by partial $A-V$ block with frequent dropped beats. The attacks of paroxysmal tachycardia could be prevented by either digitalis or quinidine.

Lewis ${ }^{1}$ published electrocardiograms of a child with auricular paroxysmal tachycardia and partial $A-V$ block with occasional dropped beats. The auricular rate was 290 per minute, and the $P$ waves were upright in Lead II. Recently, Katzit has published the enrves of three patients who had partial $\mathrm{A}-\mathrm{V}$ block during paroxysms of auricular tachycardia. The first of these showed auricular rates of 180 to 125 and block varying in degree from dropped beats to $2: 1$. The second had an auricular rate of 158 and $2: 1$ block. The third patient had an auricular rate of 167 and frequent dropped beats. In all three cases the $\mathrm{P}$ waves were upright during the paroxysms. These cases are not included in the table because the clinical data were not given.

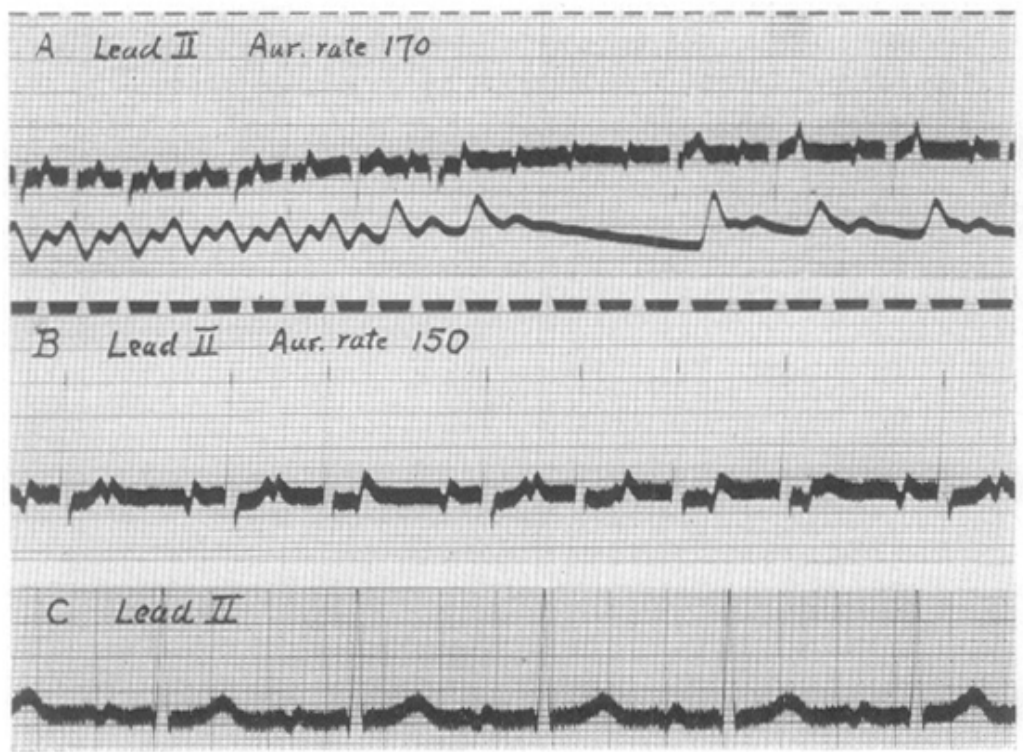

Fig. 1.-Case 1, A, March 22, 1922. Lead II and radial pulse. Auricular rate, Normal rhythm, rate 90 .

\section{CASE REPORTS}

CASE $1 .^{*}$-A white man, aged 39 years, was first seen in 1922. He complained of attacks of palpitation and dyspnea brought on by exertion. These began in 1913, and had been worse since 1917. Examination revealed no evidence of organic leart disease and no signs of congestive cardiac failure. The electrocardiogram (Fig. $1, A$ and $B$ ) showed diphasic $\mathrm{P}$ waves, occurring at a rate of 170 per minute.

*This case is included through the kindness of Dr. John Parkinson, London, England, who generously furnished the electrocardiograms and the clinical data. 
Partial A-V hlock of varying legree $(1: 1,3: 2,2: 1)$ was prosent. Full doses of quinidine sulfate had no effect on the auricular dofleetions. The average ventricular rate was somewhat increased and the ventricular amplexes beame aberrant. One week later digitalis was griven in full foses. This in masad the degree of A-V

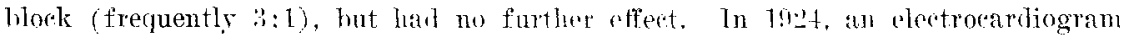
whoweil normal rhythm with diphasir $P$ waves and a rate of 90 (Fig. 1, $C$ ). In 1927, the patient sated that le' had heen fairly well, amd 1raings again showed normal rhythm with diphasie P waves and a rate of 100.

(use 2.-A white man, 32 years of age, was first seen Oct. 24, 19:37. At the age of 12 years he had rheumatie fever. He had a brief attack of tarhycardia in 1928, and another in 1929. After that lie hall frequent attacks of tachyeardia, hrought on hy slight exertion, hy ating large meals, or hy constipation, and sometimes relieved by rest. The paroxyms sometimes lasted for sereral hours or days, and were then arcompanied by shorthess of breath and soremess in the region of: the liver. They hecame so frequent, so prolonged, so serore, and so resistant to treatment that reaurse was hat to morphine, with resulting aduliction.

When first seen, the patient was exhausted from a prolonger attack of tachycardia. The leart rate was 2010 . the rhythm rogular. Pressure upon the carotin sinus raused no dhange. Merholyl, in a dose of 25 ms.. Was given subertaneously, and repeated fiftesn minutes later. After this the heart rat herane a little slower, and upon carotid sinus pressil's it fiell to a normal level. Almost immediately, however, the rapia beating returnal.

At this point the first electromardiogram was taken; it showed auricular flutter with an aurieular rate of exti, and $3: 1$ ventricular respomse. Digitalis, in a dose of $0.5 \mathrm{Gm}$, was given intalenously, and thirty minutes later the electrourdiogram (Fig. 2, t) showed aurieular flutter with an aurieular rate of 275 and a ventricular rate of 82 per minute. On Ortober 29 , digitalis, in a lose of 0.35 (tm., was griven intravenously. On Nowmber l. the pleetrocardiogram (Eig. 2, B) showed aurienlar paroxysmal tachyeardiat with aureular and ventricular rates of 200 . Digitalis (0.35 Gm.) was given intravenously, and tittefen minutes later there was $2: 1 \mathrm{~A}-\mathrm{V}$ block; 1 he aurieular rate was still 2011 (Fig. :-, (†). After this, ligitalis was given orally

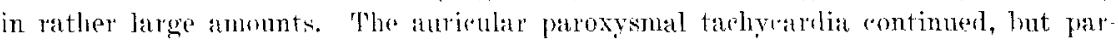
tial A-V blosk was matintained, ant on November wh the electrocardiogram (Fid. $2, D$ ) shower an atureular mate of goo and a venticular rate of 64 , sometimes even lower. Precordial leads were userl in orler to obtain latge aurieular deflections. At this time digitalis was stopued herase of symptons of mile intoxieation. On November 26 there was $1: 1$ rentricular response with a rate of 200 . Carotid sinus pressure causen partial hlock. After giving meeholyl $4.5 \mathrm{mg}$. subcutaneously), arotid sinus pressure aused fronounced slowing of the ventricles. Frophageal leals were used to record this (Fig. 2. E). and showed hage auricular deflections separated hy periods of electrical quiesence. Digitalis was resumed, on Dec. ac, 1937, normal rhythm was prowent (Fig. $-F$ ). For seveml months after this there were many attatks of tarlycardia. The patient then improved and it was thonght that normal rlythm was present murle of the time. At this time the murmur of mitral stenosis was heard. On Oct. "2s, 1934, however; an electrocardiogram showerl auricular flutter in Cuals I and II, with an aurieular rate of 292 and a $t:$ ] ventricular response. A minute later, when Iead III was taken, auricular fibrillation was present, with a ventricular rate of 80 . In oriler to hing out the auricular

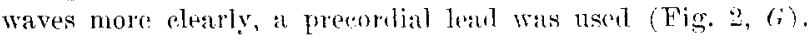

(Ass: 2.-A white man, aged 41 yaurs, was first seen on Jan. 5, 1938. For one month he had been having attacks of tachycardia, shortness of breath, and dizziness. They occurred irregularly every few days and lastel a few minutes. They were abrupt in onset and termination, and were brought on by exertion and relieved by 
rest. Similar attacks had occurred one year previousily and again six moutls previously, each time for a period of a few weeks.

Physical examination was entirely negative. No abnormality of the heart was detected. The blood pressure was $118 / 60$. The rhythm was regular, the rate, 100 . With moderate exercise, however, the rate rose to more than 160 ; the rhythm was regular. After about thirty seconds the rate dropped abruptly and the rhythm was
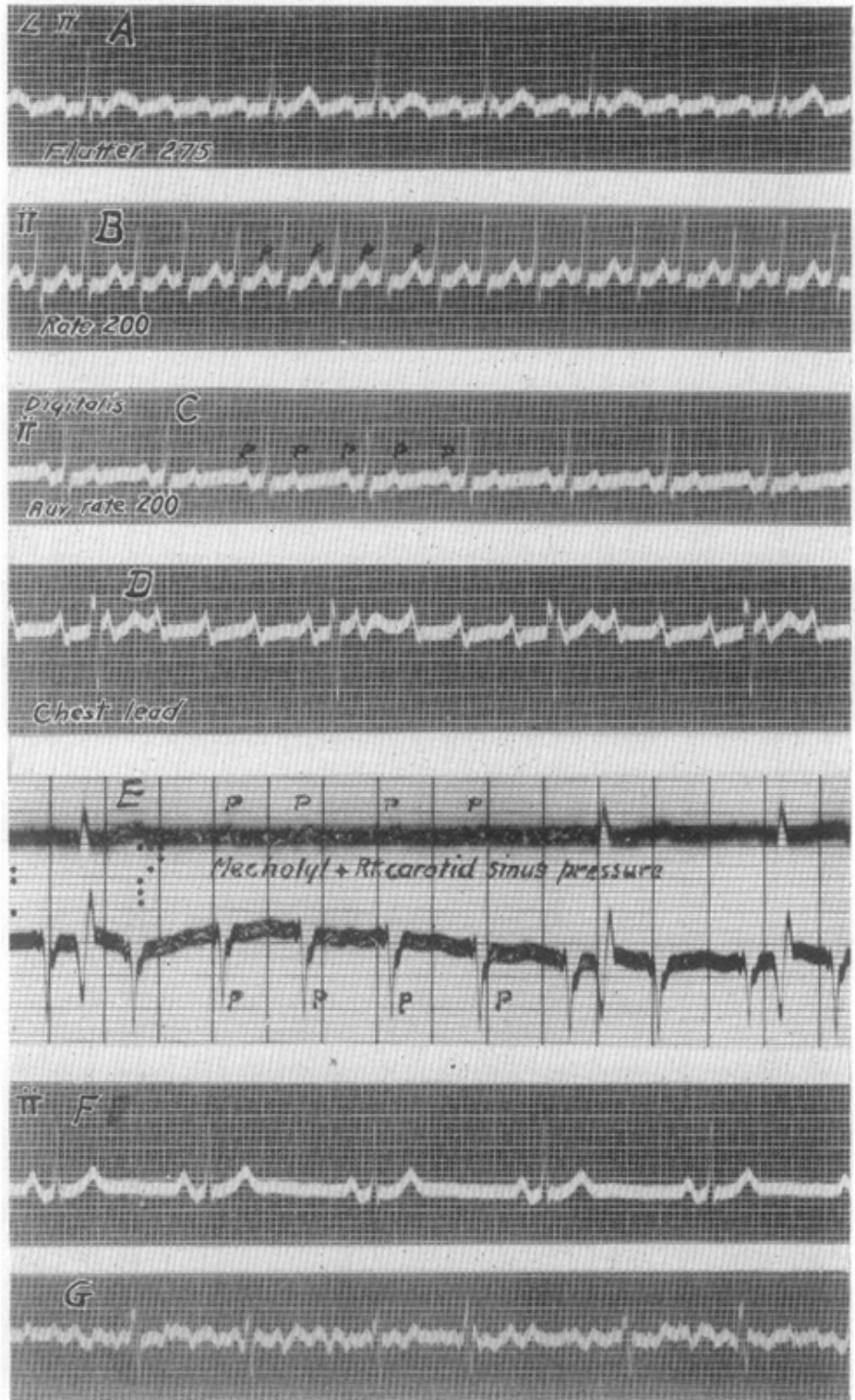

Fig. 2.-Case 2. A, Oct. 28, 1937. 'Lead II. Auricular flutter. Auricular rate 275, ventricular rate, $82 .{ }^{A} B$, Nov. 1, 1937. Lead II. Auricular paroxysmal tachycardia with auricular and ventricular rates of 200 . Patient had had digitalis $(0.85 \mathrm{Gr}$.). $C$, Nov. 1, 1937. Lead II, 15 minutes after $0.35 \mathrm{Gm}$. of digitalis intravenously. Auricular paroxysmal tachycardia with 2:1 A-V block. Auricular rate 200, $D$, Nov. 22, 1937. Precordial lead. Auricular paroxysmal tachycardia with high grade partial $A-V$ block. Auricular rate 200 . Patient had had large amounts of digitalis. $E$. Nov. 26, 1937. Learl I and esophageal lead. Pressure upon right carotid sinus after $25 \mathrm{mg}$. of mecholyl subcutaneously. $F$, Dec. 29. 1937. Lead II. Normal rhythm. $G$, Oct. 1 , 1938. Precordial lead. Auricular fibrillation. 
irregular for 10 or 15 beats. Thereafter the heart beat regularly at a normal rate. The exercise was repeated and the same rhanges in rate and rhythm were again observed.

An electrocardiogram (Hig. 3, A) showed paroxysmal tachyeardia with an aurieular rate of 200 and partial A-V block, usually 3:1. A precordial lead (Fig. 3, B) was employed to show the auricular waves more clearly. Fxercise permitted the ventricles to follow the auricles at their full rate for a short time, after which the partial block returned. Carotid sinus pressure and mecholyl failed to terminate the auricular tachycardia. Quinidine sulphate, in a dose of $0.4 \mathrm{Gm}$. orally, was followed in two hours by slowing of the auricles to 174 ; the ventricles followed at
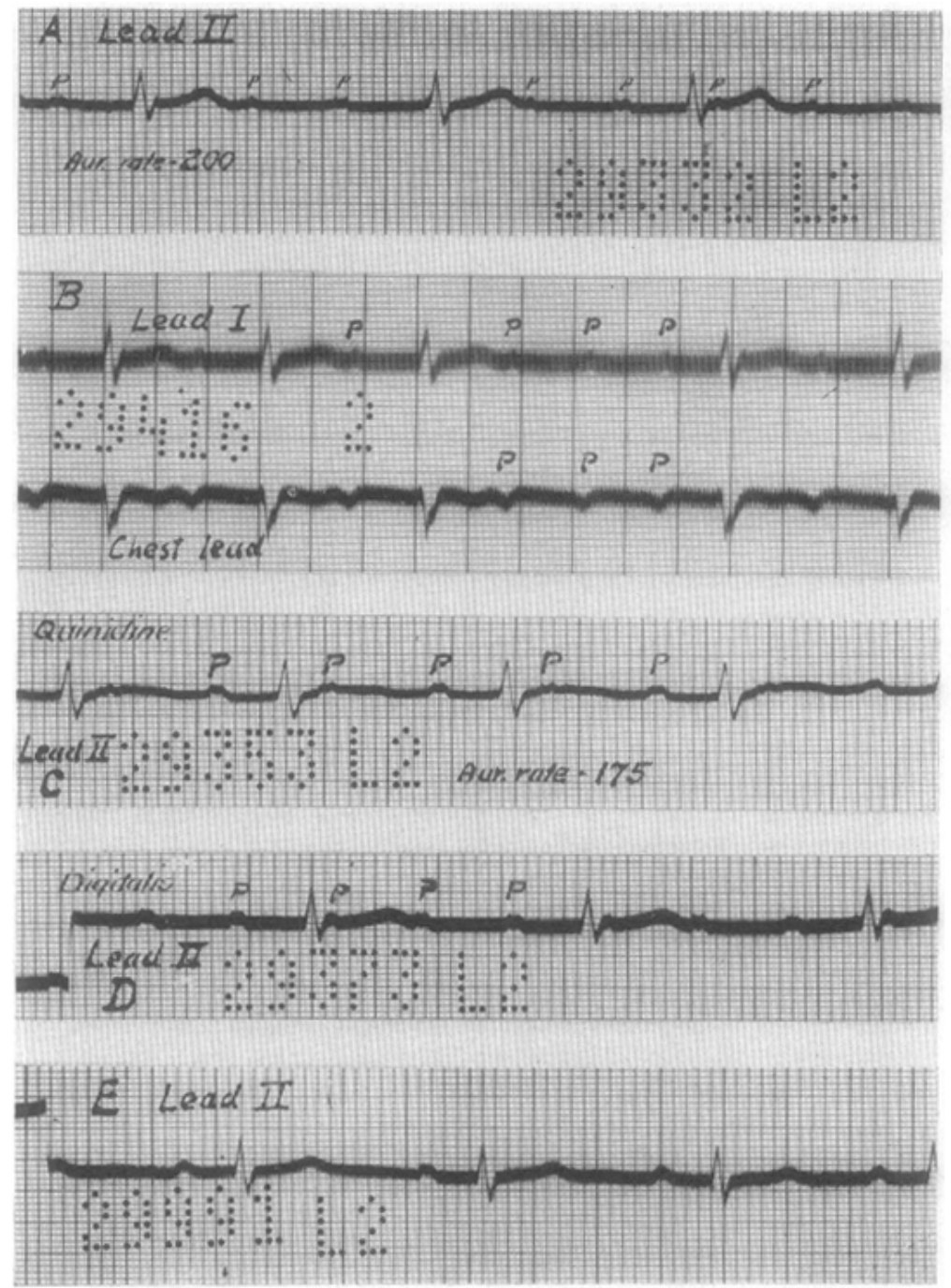

Fig. 3.-Case 3. A, Jan. 5, 1938. Lead II. Auricular paroxysmal tachycardia with partial A-V block. Auricular rate 200. Ventricular $78 ., B$, Jan. 5, 1938. Lead I with partial A-V block. Auricular rate 20 upon right carotid sinus. Auricular rate above and precordial lead below. Pressure upon right carotid sinus. Auricular rate 200. C, Jan. 7, 1938. Lead II, 2 hours after 0.4 Gm. of quinidine sulfate. Auricular 87. D, Jan. 10, 1938. Lead II after $1.3 \mathrm{Gm}$ of digitalis. Auricular paroxysmal tachycardia with $3: 1 \mathrm{~A}-\mathrm{V}$ block. Auricular rate, 202. Ventricular rate, $67 .{ }_{E}$, March 17. 1938. Lead II. Normal rhythm, rate 88 . Had taken digitalis regularly, 
half the auricular rate (Fig. $3, C$ ). Normal rhythm, however, was not restored. The patient was then digitalized without affecting the auricular rate. The degree of block, however, was increased, usually to $3: 1$ (Fig. $3, D$ ), and the rapid ventricular beating upon exertion was prevented. After digitalization it was observed that mecholyl, in a dose of $15 \mathrm{mg}$. subcutaneously, increased the auricular rate from 207 to 218; the ventricular rate rose to 109 .

Digitalis was continued. The patient returned January 26 , at which time he had complete relief from his symptoms. The auricular rate was 211 , and the ventricular rate, 86, with a mixture of $2: 1$ and $3: 1$ bloek. On March 17 the patient stated that he had been entirely free of symptoms, and the electrocardiogram showed normal rhythm (Fig. 3, E).
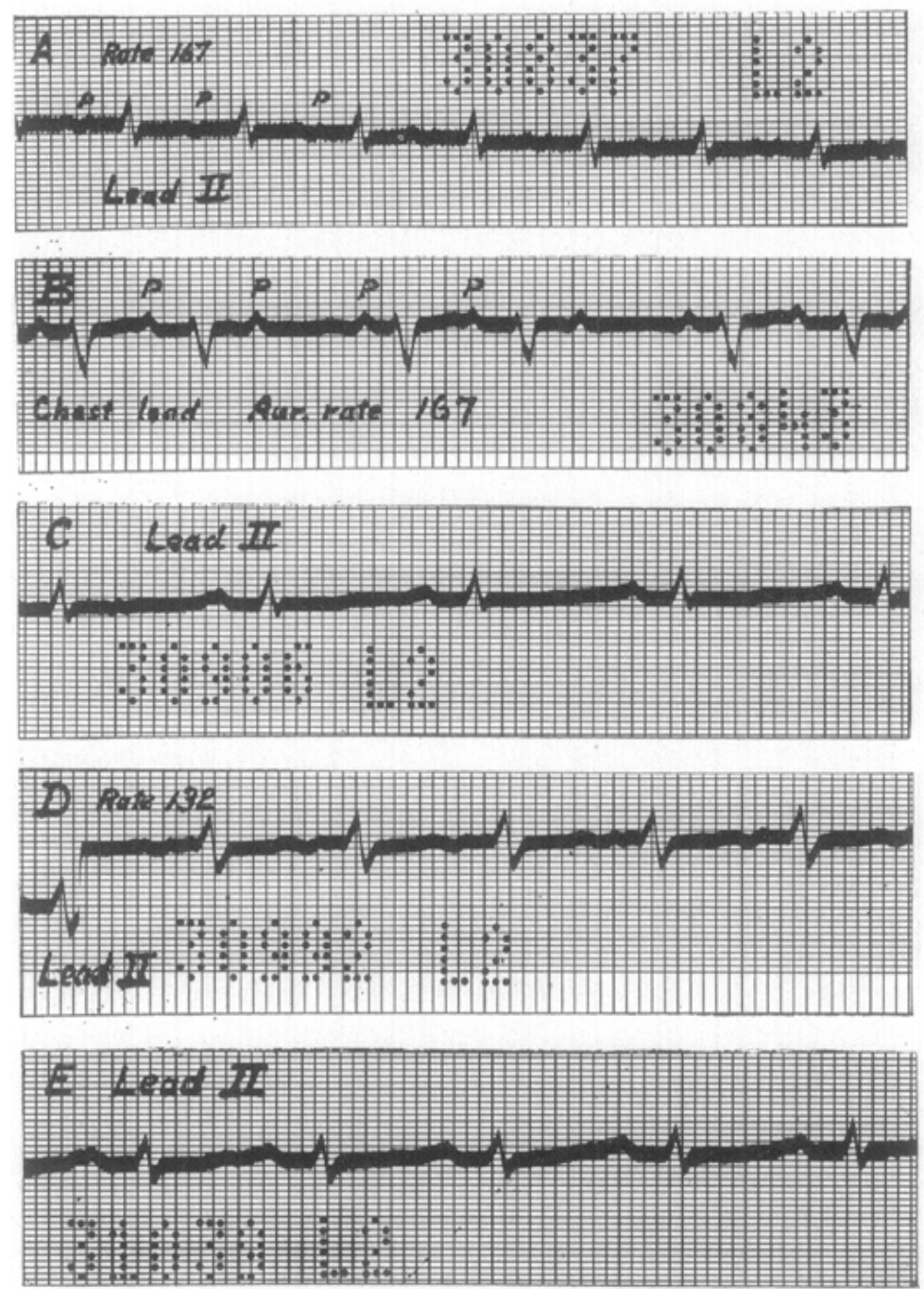

Fig. 4.-Case 4. A, June 21, 1938. Lead II. Auricular paroxysmal tachycardia, rate 167. Patient had received quinidine and digitalis. $B$, June 21,1938 . Precordial lead, with carotid sinus pressure. There is partial A-V block with dropped beats. The auricular deflections are shown more clearly. Auricular rate 167. $O$, June 29 1938. Lead II. Normal rhythm. Rate 97 Had had digitalis and quinidine. $D$, July 11, 1938. Lead II. Auricular paroxysmal tachycardia with $1: 1$ ventricular response Rate 132. Had had digitalis and quinidine. $F$, July 18, 1938. Lead II. Normal rhythm. Rate 107. 
Gase 4.-A white bov, 15 years of agr, was arlnitted to the hospital .lune 3 , 1938. He had been in excellent bealth until Jay 1, 19:8s when he began laving shortness of breath upon moderate exertion, tachyourlia, wakness, and an unproductive cough. The palienl was not aware of an abrupt ouset, nor was there any known infection at the time. The tachycardia yersisted arould 200 per minute in spite of rest in bed. The shortness of hroath was increased by lying flat. Digitalis slowed the ventrieles by produring partial $\mathrm{A}-\mathrm{V}$ block. Quinicine slowed tle aurie-

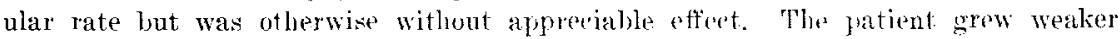
and more dyspneie, and the liver herame enlarget. He was then retered tor the hospital.

Upon physical examination the patient sppeared seriolsly ill, with a dusky eyanosis, and dyspnea upon lying flat. The leart was moderatrly enlargerl. There was a systolic murmur over the entire heart, londest at the apex. No diastoliu: murmur was heard. The rate was about 160 ; the rhythm was not remarkable apart from an occasional, slight irregularity. The blool pressure was $92 / 70$. The lungs were normal. The liver was slightly enlargerl. There was no whind.

Roentgenologic examination showed fairly markel carclia anlargement.

The electrocardiogram showet a loart rate of 167 ; the rhythm was regular except for oceasional dropped beats (Fig. $t, 4$. Procordial leads showed the alurieular deflections more clearly. Pressure upon the arotid sinus inmerased the legree of A-V block, eausing frequent dropped heats (Fig. 4, $B$ ). Quinidine was withleld, and the auricular rate rose to 176 ; them quinidine was resumed and the auricular rate fell to 150 . After the alministration of both digitalis aud quinine for several days, normal rlyythm returned (Fig. t, (:). In a few days, however, the tarlycardia returned and persisted, expept for in brief period of normal rhythm on . July 18 (Fig. 4, E). During the ectopice aurieular tachyearlia, the rate slower to 1,id under digitalis and quinitine (Fig. 4, D). The fatient grew progressively worte; he showed no improvement during the interlules of nomml rlythm or when the rate slowed to 132. Râles appeared in the lungs and edema of the lexps developed. The patient died July 24 , 1938, of cardiar failuro.

At autopsy the leart weighed 50 o grams. It showed myourdial liyintrophy

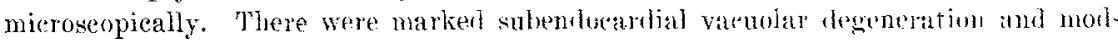
erate subepicardial fatty infiltrution. Infurelion of the left rantrielo in the region of the conduction apparatus was found. There was also a tegemeritiwe subendocardial lesion in the left rentriele, with noworis, lymplocytio intiltration, and tibro blastic proliferation. An organizing mural thrombers was prosent in the loft ventricle. There was endocardial solerosis.

The lungs showed an acote exarobation of chronic passive congestion, with

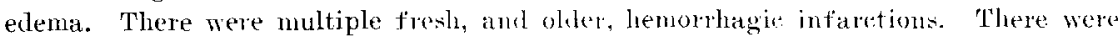
arganizing thrombi in the pulmonary roins. The smaller arteries were selerotie. There was an embolus in a merliun-siznt pulmonary artery, and a bland embolus in the main pulnomary artery. Arute foudent foronehitis and tominal purnlent lobular plleumonia vere present.

The liver and spleen showel chronie passive eongestion.

CAse 5.-A white woman, aged 62 years, entered the hospital July 11, 193 s. During the previous ten months she had had recurring attacks of left-sided renal colic, suffered from increasing woakness, and lad lost 35 pounds in weight. During this time she was short of bratl upon moderate exertion, and experienced frequent palpitation and irregularity of the leavt. There wat oerasional strelling of the ankles.

Physical examination showed that the hetrt was nolmal in size. 'There was a systolie murmur at the apex. The rate varied from 106 to 140 . There was an irregularity which was attributed to dropped beats. The blood pressure was $130 / 85$. The radial and brachial arteries were thickened. The lungs were normal. The 
abdomen was negatice. There was no edema. The isthmus of the thyroid contained a small adenoma.

Roentgenologic examination showed no abnormalities of the heart or lungs, but did reveal a renal ralculus on the left side.

The electrocardiogram showed an auricular rate of 16r. Partial A-V block, with frequent dropped beats, was present, and the rentricular rate was 134 (Fig. 5, A). Carotid sinus pressure increased the degree of block and slowed the ventricles, but did not alter the auricular mechanisn (Fig. 5, B). After digitalis in full doses, normal rhythm returned (Fig. $5, C$ ). The patient was sent hack to her home physician for nephrectomy.
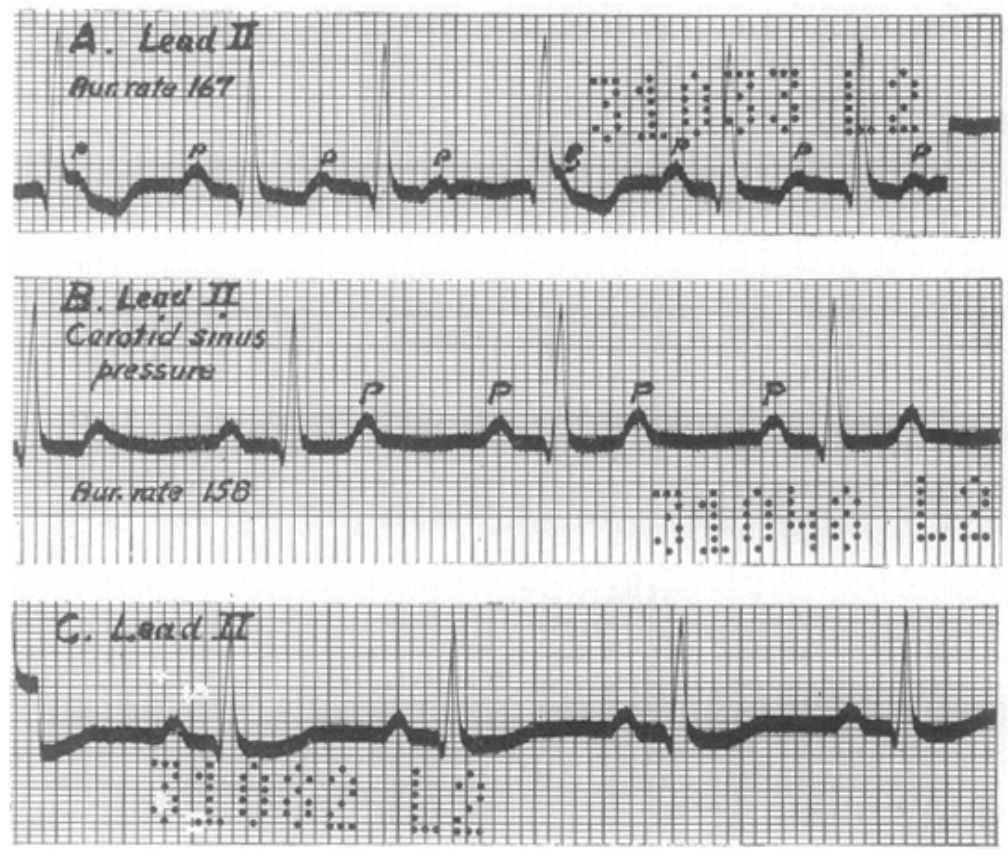

Fig. 5.-Case 5. A, July 18, 1938. Lead Ir. Auricular paroxysmal tachycardia with partial $A-V$ block and frequent dropped ventricular beats. Auricular rate 167. $B$, July 19, 1938. Lead II. Carotid sinus pressure produces $2: 1 \mathrm{~A}-\mathrm{V}$ block. Auriculai rate 158. C, July 22, 1938 . Lead II. Normal rhythm. Rate 93. Had had digitalis.

CASE 6.-A white man, 19 years of age, was admitted to the hospital July 18 , 1938. In 1930, the patient had had epigastric pain, nausea, and vomiting; these were attributed by his physician to heart disease, and were relieved in a few days by rest and digitalis. After that he took digitalis almost continuously and restricted his activities. Similar symptoms returned in 1933, and again in January, 1938. In each instance they followed strenuous exertion and were relieved by rest in bed. In January, 1938, he had a brief, acute respiratory infection. After that he had dyspnea and pronounced tachycardia upon moderate exertion. The heart was slow during rest. He improved under larger doses of digitalis and a month of rest in bed. The tachycardia upon exertion persisted, however, and he was referred to the hospital. There was no history of rheumatic fever.

The physical examination was entirely negative with the exception of the heart. It was markedly enlarged, with dullness extending to the left anterior axillary line. There were systolic murmurs at the apex and base. The rate and rhythm varied. At times the heart was regular at a rate of 60 , at other times regular at a rate 
of 170. Oceasionally the rhytlm was irreguar and the ratio intermediate hetween the two extremes. The blood pressure varied witlin normal limits. There were no signs of congestive cardiae failure.

Roentgenologir examination showed marked cardias mlargement.

The electrocardiograms showed tachyardia of auricular origin, with a rate of 162 and $2: 1 \mathrm{~A}-\mathrm{V}$ block (Fig. 6, A). After mild exercise there was transient $1: 1$ ventricular response with no thange in auricular rate. Carotid sinus pressure in
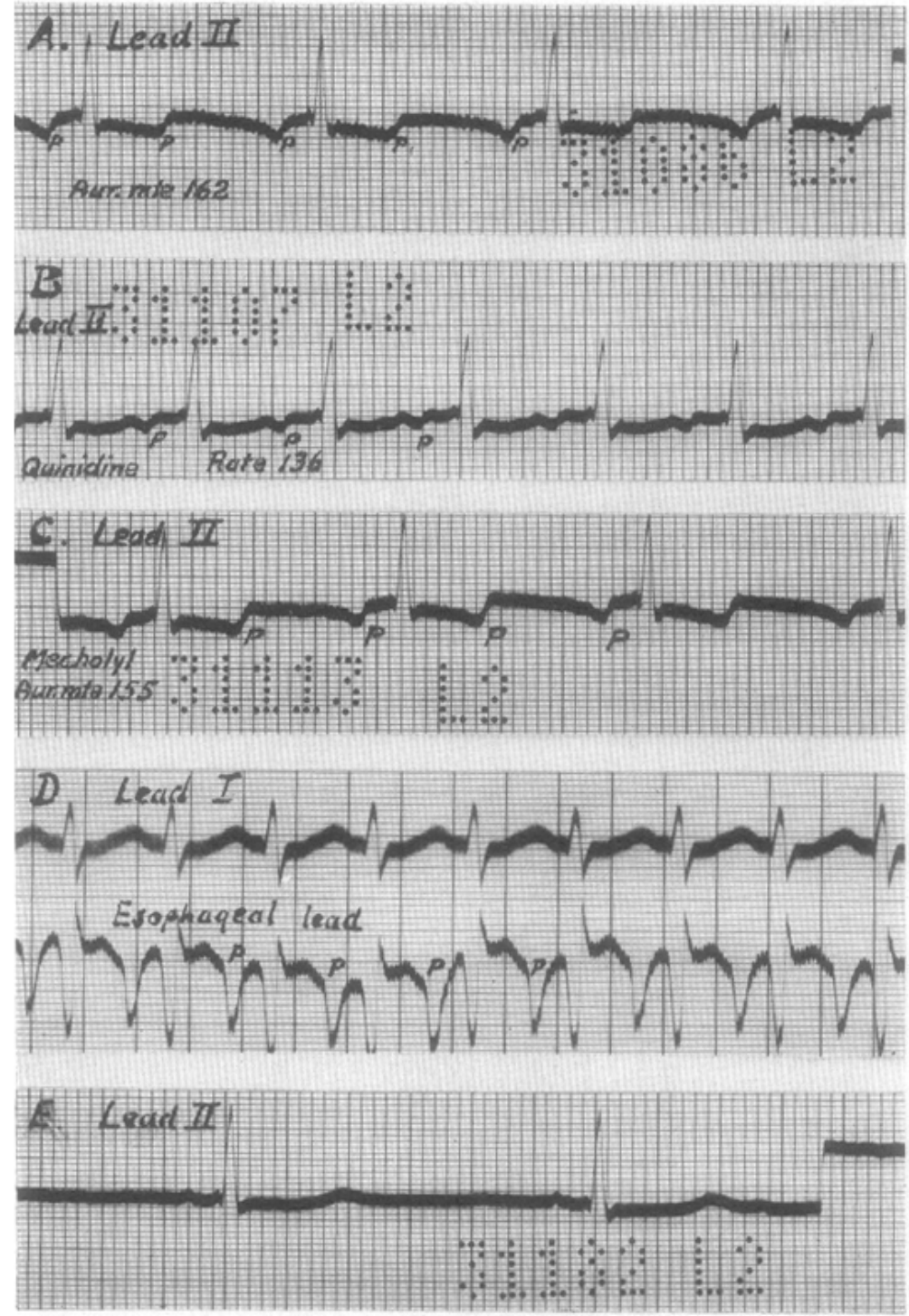

Fig. 6.-Case 6. A, July 22, 1938. Lead II. Auricular paroxysmal tachycardia with 2:1 A-V block. Auricular rate 162 . Had had digitalis. $\boldsymbol{B}$, July 25,1938 . Lead II. Auricular paroxysmal tachycardia with 1:1 ventricular response. Rate 136 . Had had digitalis and quinidine. $C$, July 26 , 1938. Lead II, taken 33 minutes after $10 \mathrm{mg}$. of mecholyl subcutaneously. Auricular paroxysmal tachycardia with $2: 1 \mathrm{~A}-\mathrm{V}$ block. Auricular rate 155. $D$, Aug. 8 , 1938. Lead I above, esophageal lead below. Auricular paroxysmal tachycardia with 1:1 ventricular response. Rate 155 . The auricular waves are very large in the esophageal lead. $E$, Aug. 3, 1938. Lead II. Normal rhythm. Rate 50. Had had digitalis and quintdine. Intraventricular block is present, but not readily apparent in this lead. 
creased the degree of block temporarily, but did not affect the aurieular mechanism or rate. Quinidine slowed the auricles to 136 , usually with $2: 1$ ventricular response, but sometimes with $1: 1$ response (Fig. 6, B). Mecholyl, in a dose of $10 \mathrm{mg}$. subcutaneously, increased the degree of block slightly, but did not alter the aurieular rate (Fig. 6, C). Normal rhythm returned on July 31, after large doses of quinidine sulfate (Fig. 6, E). On August 7 auricular paroxysmal tachycardia returned (Fig. 6, D). Normal rhythm was resumed after $0.9 \mathrm{Gm}$. of quinidine on August 8, and persisted thereafter. The patient was given quinidine sulfate in a dose of 0.3 Gm. three times daily. He felt quite well and there was no evidence of quinidine intoxication. He died unexpectedly in his sleep on Aug. 13, 1938.
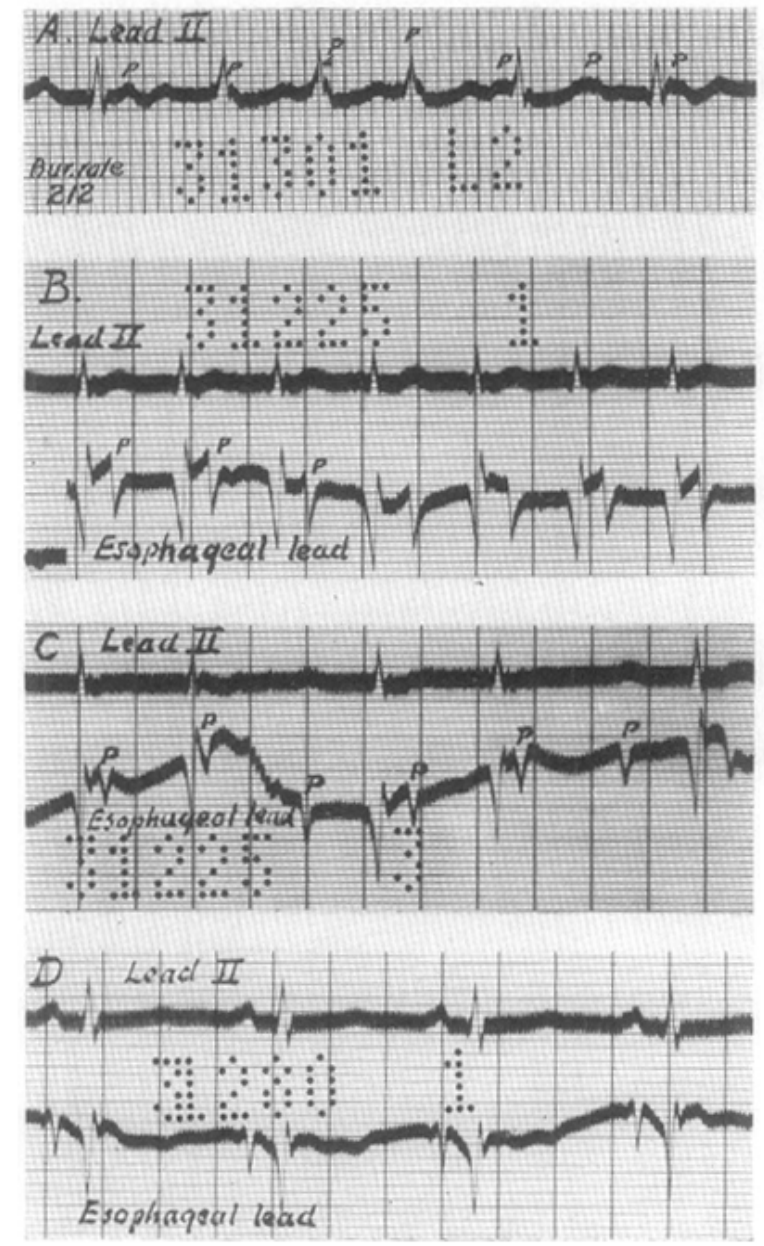

Fig. 7-Case 7. A, Aug. 17, 1938. Lead II. Auricular paroxysmal tachycardia with partial $A-V$ block and many dropped ventricular beats. Auricular rate, 212 Had had digitalis and quinidine. $B$, Aug. 6,1938 . Lead II above, esophageal lead below. There is 1:1 ventricular response. $C$. Same as $B$, but showing partial A-V block. $D$, Aug. 13, 1938 . Lead II above, esophageal lead below. Nornal rhythm. The auricular deflections are very large in the esophageal leads.

Autopsy showed hypertrophy of the left ventricle, the lateral wall of which measured $28 \mathrm{~mm}$. in thickness. There was an old mitral valvulitis, with minimal deformity of the valve. The right side of the heart was dilated. The lungs showed congestion and edema, patchy emphysema, and atelectasis. There were acute puru- 
lent bronchitis and microscopie beonchiectasis. The persistent byperplastic thymus, generalized lymphoid hyperplasia, and hypoplasia of the auta and adrenals suggested thymicolymphatic ronstitution. There was shight "hronic rholecystitis, and the liver contained foei of leurocytes. The hrain was not cramined.

CASE 7.-A white man, aged 67 years, entered the hospital Aug. 1, 1438. He had been in good health until seven years previously, when he hat a sudden attack of dyspnea which was relieved by atrenalin. Thereafter he lad dyspnea when excited, and then upon moderate exertion; this increased in serority until finally he was short of breath at rest, and for the preceding few weeks he had been orthouneic. He spent the ten days before admission in a rhair because of dyspnea, swell-

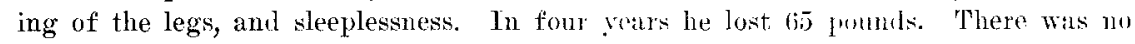
cough, wheezing, or chest pain.

Physical examination showed that the chest was emphysenatous, with hyperresonance more pronounced on the right side. The breath sounds were absent over the right side of the chest, except in the interscapular region, where they scemed normal. There were râles at the base of the left lung. The heart was not definitely enlarged; the rate and rlythm were normal. There were no murmurs. The bloot pressure was $180 / 106$. The peripheral arteries were selerotic. There was marken alema of the ankles.

Roentgenologie examination showed emplysema of the lungs, pneumothorax on the right, an old fibrotic scar at the loft apex, and probably an inflammatory lesion at the right base. There was no alonormality of the heate or aortat.

The electrocardiogram on August 1 slowed ocedsional auricular extrasystoles, but was normal in otler respects. Dignitalis was given in full loses. Tho patient had several attacks of auricular paroxysmal tachycardia, with partial A-V block (Fig. 7). Esophageal leads were employed to show the auricular deflections mor alearly. The tachyeardia was controllet my by fairly large doses of quinidine. The pneumothorax and edema cleared up satisfactorily, and the paroxysmal tachycardia did not return. The dyspnea upon slight exertion persisted. L pon one oecasion tracings showed what was probably $A-T$ nodal rlythm, with a rate of $88 p^{2} r$ minute; the rhythm was regular, hut no auricular waves could be illentifiel.

Gase $x .-1$ white man, 5), years of age. entered the hospital Aug. 25,1939 . For the preceding eighteen months he hat suffered from fatigur, shortness of breatl, and swelling of the legs. For inany years he hat hat a culud proturtire of rellowish sputum.

Physical examination showed amatiation, dyomea, ayanosis, and pronounces edema of the feet, legs, and thighs. The lungs were resonant, but contained numprous erepitant and coarse râles throughout, and there were suall areas of bronchovesicular breath sounds over the upper lobes. The heart was ronsiderably enlargeil, and there was a loud systolie murmur over the lower end of the sternum. The rhythm was regular except for occasional extrasystoles. The blool pressure was 110/78. The peripheral arteries were thickoned. The liver was slightly enlarget.

Roentgenologic examination showed marked enlargement of the lieart. In the lungs there weie increased rascular shadows and also areas of intanmatory infiltattion.

The electrocardiogram on August 26 showed normal rhythm, with occasional ventricular extrasystoles. There was right :xis deviation, with inverted $T$ waves in Leads II and III (Fig. 8, A). The patient was given digitalis in moderate amounts and improved temporarily, but there was no striking change at any time. On August 30 the electrocardiogram (Fig. 8, B) showed auricular paroxysmal tachycardia with an auricular rate of 188, and partial $\mathrm{A}-\mathrm{V}$ block with a ventricular rate of 112. Later the rhythm became regular at a slower rate, and the curve of Sep- 
lember 1 showed what was probably A-V nonlal rlyythn (Fig. 8, C), without any deffections which could be identified as $P$ wares. The patient then grew gradually worse and died Sept. 5, 1939.

Autopsy showed bilateral saceular and tubular bronchiectasis and bronchiectatic abscesses. There were mucopurulent bronchitis and an old fibrous tuberculosis of the lungs and bronchial lymph nodes. The heart weighed 400 grams and showed right-sided dilatation. 'lhere were myocardial liypertrophy and brown atrophy. There were extensive subendocardial fibrosis and subepicardial fatty infiltration. There was minimal selerosis of the coronary arteries and of the mitral and tricuspid valve leaflets.

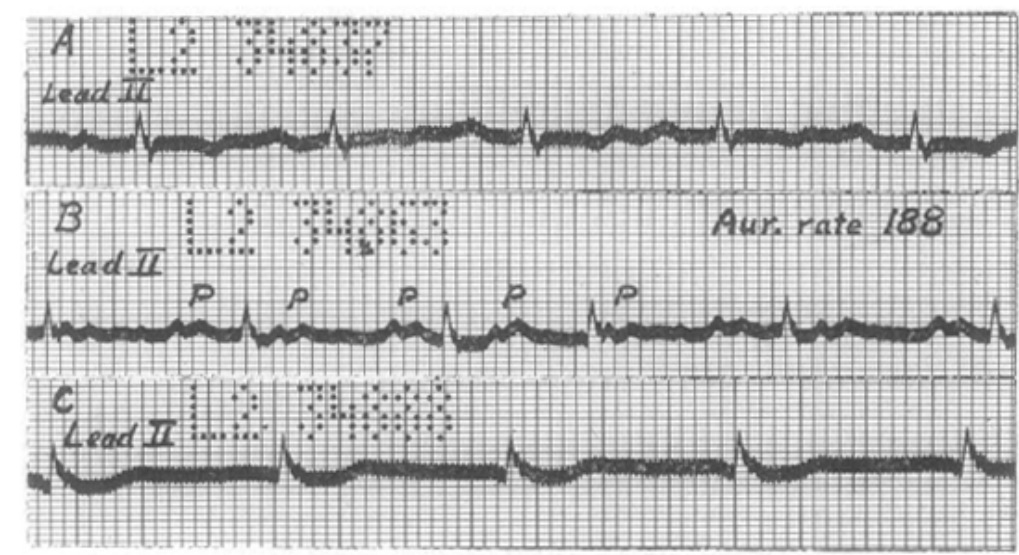

Fig. 8.-Case 8. A, Aug. 26, 1939. Lead II. Nomal rhythrn. Rate 107. B, Aug. 30, 1939. Iead I1. Auricular paroxysmal tachycardia with partial A-V block, usually 2.1 Auricular rate 188. Had had digitalis. $C$ sept 1939 . Lead 11. Probably A-V nodal rhythm. Rate 88 . No auricular deflections visible.

CASE 9.-A white woman, 23 years of age, was followed closely throughout the winter of 1939-1940, during a pregnaney. She gave a history of rheumatic fever in childhood, but toleraterl exertion fairly well. Exainination showed very slight cardiae enlargement, a blowing systolic murmur at the base, a high-pitched diastolic murmur at the left sternal margin, and a low-pitched diastolic murmur at the apex. The rate and rhythm were normal. The blood pressure was usually about 100/60. There were no signs of congestive failure.

The patient did well until March 7,1940 , when she developed acute edema of the lungs, from which she made a gool recovery. On April 30, 1940, when alnost at term, she was delivered of a normal infant by low Caesarean section, from which she recovered satisfactorily. Digitalis was continued in a lose of $0.1 \mathrm{Gm}$. daily. The cardiac rliythn remained normal throughout.

On July 18, 1940, she had a short attack of palpitation. On July 20 she developed shortness of breath and rapid, violent beating of the heart upon very slight exertion. Physical examination showed nothing new except slight cardiac irregularity and rather pronounced pulsation of the neck veins. The cardiac rate was 100 . Upon rather mild exertion the rate rose to 210 and the rhythm was regular. The rate gradually fell to the previous level and slight irregularity returned. Pronounced but transient slowing was produced by carotid sinus pressure.

The electrocardiograms, which had previously shown normal rhythm, with broad, notehed $\mathrm{P}$ waves (Fig. 9, $A$ ), now showed auricular paroxysmal tachycardia with an auricular rate of 195 (Fig. 9, B). There was high-grade partial A.V block, with a ventricular rate of 100 . After exercise the auricular rate was 219. The 
ventricles responded to each auricular beat for a short time (Fig. 9, C), then be came slower and irregular, and finally displayed a long period of near standstill, interrupted by idioventrieular beats ( $F i g .9, D$ and $E$ ), at the end of which they resumed their previous rate of 100 per minuto.

The dose of digitalis was increased for a few days, but the shortness of breath and palpitation continued, although they were less easily brought on. Quinidine was given and the patient foleruted moderate exertion without symptoms. The quinidine was stopped for a few days and the palpitation and shortness of breath returned. When quinidine was resumed the symptoms reased. Since then quinidine has been taken irregularly. Tachycardia occurs every few days, often when quinidine has not been taken. Small amounts of quinidine are followed by normal rhythm in one or two hours.
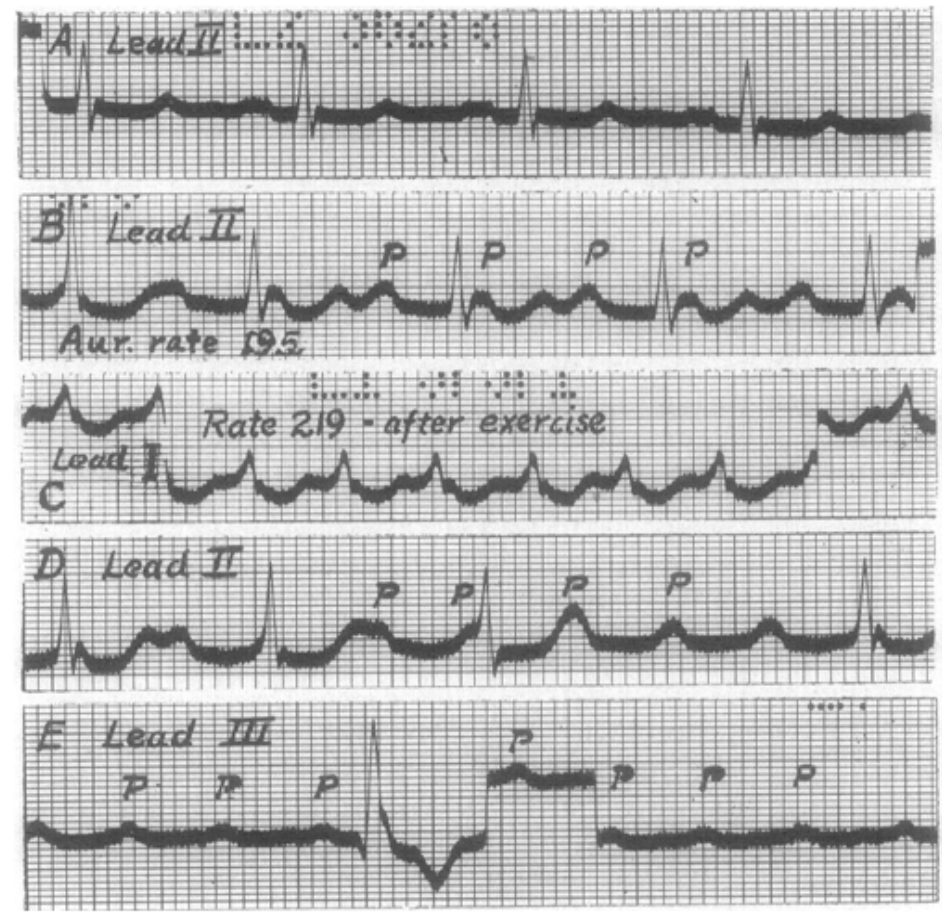

Fig. 9.-Case \%. A, March 12, 1940. Lead II. Normal rhythm, rate 90. $B$, July 20, 1940. Lead II. Auricular paroxysmal tachycardia, with partial A-V block. Auricular rate 195. Ventricular rate 100 . Patient had had digitalis. $C, D$, and $E$ Leads I, II, and III, resp., July 20, 1940. After exercise, $1: 1$ ventricular response is followed by slowing and irregularity of the ventricles, with a period of ventricular near-standstill interrupted by idioventricular beats.

CASE 10.-A white man, aged 54 year's, was first seen Feb. 14, 1940. His blood pressure had been somewhat elevated for about six years, but there lad been no symptoms associated with his hypertension except nocturia. The patient considered himself in good health until Feb. 12, 1940, when he had an attack characterized by a feeling of numbness in the precordium, nausea, and profound weakness. There was no pain or shortness of breatl. Examination showed that the patient was overweight. There was slight enlargement of the heart, but no murmurs. The rate was about 70 , and there were frequent premature beats. The blood pressure was 150/125. The remainder of the examination was negative. The electrocardiogram (Fig. 10, A) showed frequent auricular extrasystoles and slight left axis deviation, with inverted $\mathrm{T}$ waves in Lead $\mathrm{I}$. The precordial leads were normal 
with the exception of inversion of the ' $\mathrm{l}$ ' waves in the lead taken in the left anterior axillary line. There were no further attacks of this type. He was given theophylline and digitalis. After digitalization the dosage of this drug was reduced to 0.1 Gm. daily, but in September he took $0.2 \mathrm{Gm}$. daily.

During the night of Sept. 21, 1940, he began having vague precordial discomfort, described as a sense of pressure or numbness or sliakiness, and nausea and romiting. There was no pain, shortness of breath, or edema. He was given digitalis (0.4 Gm.) on September 23. Physical examination on September 24 showed that the heart was slightly colarged. The rate varied between 44 and 52 per minute. There were periods of higeminy. At times there were numerous premature beats. At other times the rhythin was regular. 'The heart sounds raried in intensity when the ventricles were beating slowly and regularly. Pulsations in the neck veins were counted at approximately 200 per minute. The hood pressure was 16it/190. The
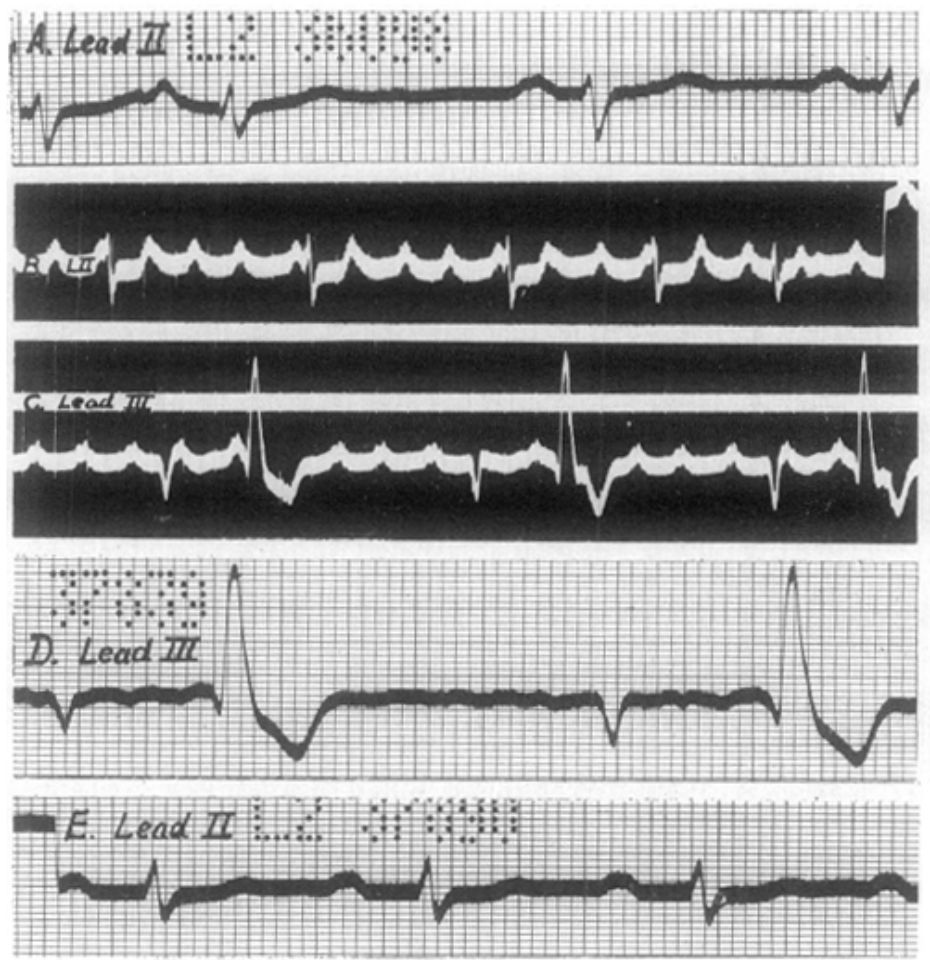

Fig. 10.-Case 10. A, Feb. 14, 1940. Lead II. Normal rhythm with auricular extrasystoles. P-R 0.20 sec. $B$, Sept. 24, 1940 . Lead II. Auricular paroxysmal tachycardia with partial A-V block. Auricular rate 200. Ventricular rate 56. $C$, Sept. 24, 1940. Lead liL. Auricular paroxysmal tachycardia with partial A-V block and extrasystolic bigeminy. Ventricular rate 58. In $B$ and $C$ the auricies are slightly irregular. Patient had been overdigitalized. $D$. Sept. 26, 1940. Lead III Auricular

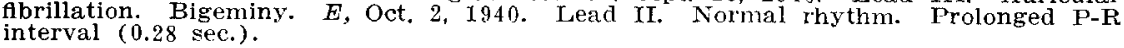

remainder of the examination was negative. The electrocardiograms showed auricular paroxysmal tachycardia with high-grade A-V block (Fig. 10, B). The auricular rate was 200, the ventricular rate, 56. There were ventricular extrasystoles and extrasystolic bigeminy (Fig. 10, C). Digitalis was stopped. Subsequent electrocardiograms showed auricular fibrillation (Fig. 10, D), and a few days later normal rhythm (Fig. 10,E). The patient dropped dead in December, 1941. 
CASE 11.-A white man, 52 years of age, whis arlmitted March 15, 1989, rom. plaining of shortness at breath and swelling of the legs. These symptoms follower an acute respiratory infertion which hat oreured three wesks provionsly,

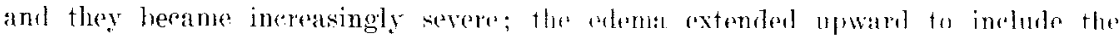

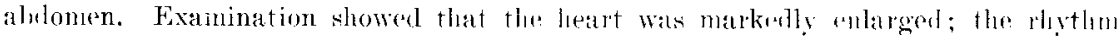
was regular and the rate was s.5. Thate were no murmats. The hlood pressure was 14t/110. Tho arteries were not tortumes. There were dullness, diminished breatl sounds, and miles at the bases of the lungs. The liver was enlarged and there was a little aseites. There was marked allemat of then lower fextremities, genitalia, and ablominal wall.

Roentgenologie examination shownel morked enlargensent of lles heart.
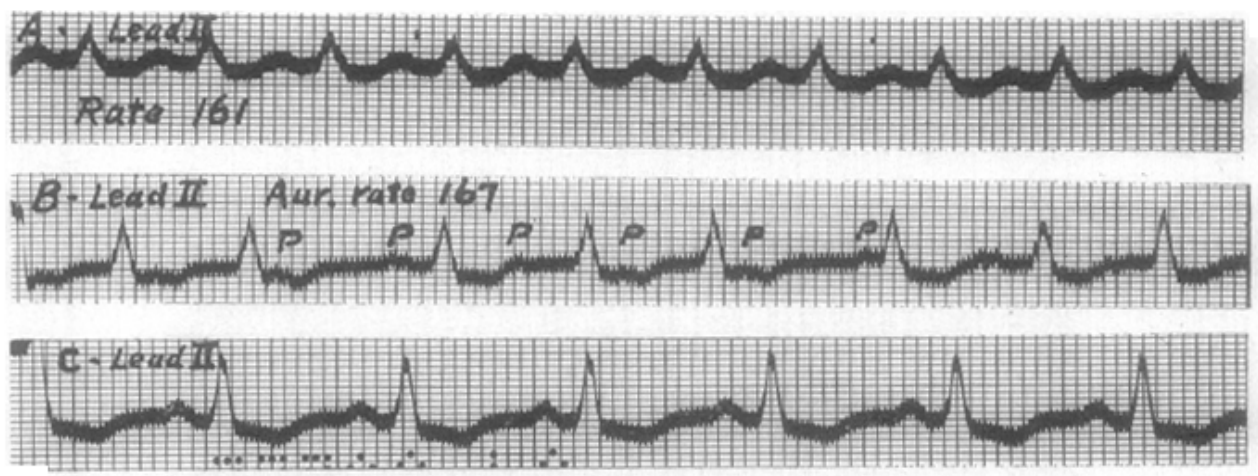

Fig. 11.-Case 11. A. March 18, 1939. Lear II. Paroxysmal tuehycardia of supraventricular origin. Rate, 161. $B$, March 20,1939 . Lead II. After 2.4 grams of digitalis in says. Auricular paroxysmal tachycarria with partial $A-Y$ block. Auricular rate $16 \pi$, ventricular rate 131 . C, March 21,1939 . 1, 24 il. Normal rhythm, rite $10 \%$.
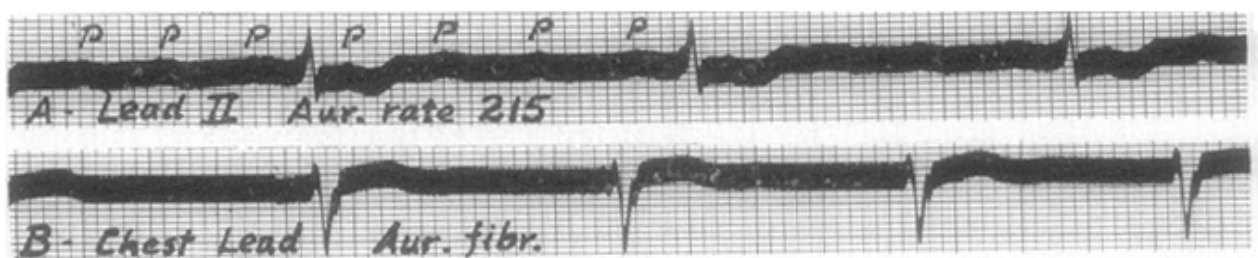

Fig. 12.-Case 12. A, Nov. 10. 1941. I Aal 11. Auricular paroxysmal tachycardia with 4:1 A-V block. Auricular rate, 215. B, Nov. 11, 1941. Trecordial lend, Anricular fibrillation, ventricular rite 60.

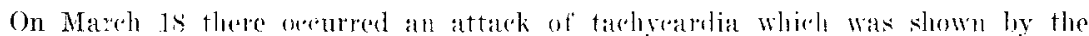

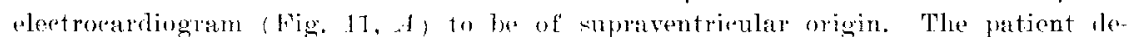
veloped acute elema of the lungs, and the hlood pressure ross to 170/120. He was almost moribund. By Mareh 20 he hit received 2.1 Gm. of digitalis in five days, and the tracing (Fig. 11, B) showed arieular parexysmal tablyeardia with partial $A-V$ block. The aurieular rate was 16 , anl the ventricular rate, 131 , por minute. On the following day normal rhythin was prosent (Fig. 11, C). After this the patient improved remarkably; thi bloor presure fell to $1: 30 /$ an and the size of the heart returned almost to normal.

(Ase 12.-A white man, aged so years, entered the hospital Nov. S, 1941, because of urinary obstruetion of three weeks' duration caused by benign enlargement of the prostate. He had suffered from shortness of breath for four years, and had been taking digitalis for three years. Fxamination showed evidence of senility 
und emaciation. The heart was slightly enlarged and was irregular; the rate was 68. There were no murmurs. The blood pressure was $110 / 80$. The peripheral arteries were thickened. The lungs were normal. The liver was not enlarger. There was edema of the left ankle which was altributed 10 varicose veins.

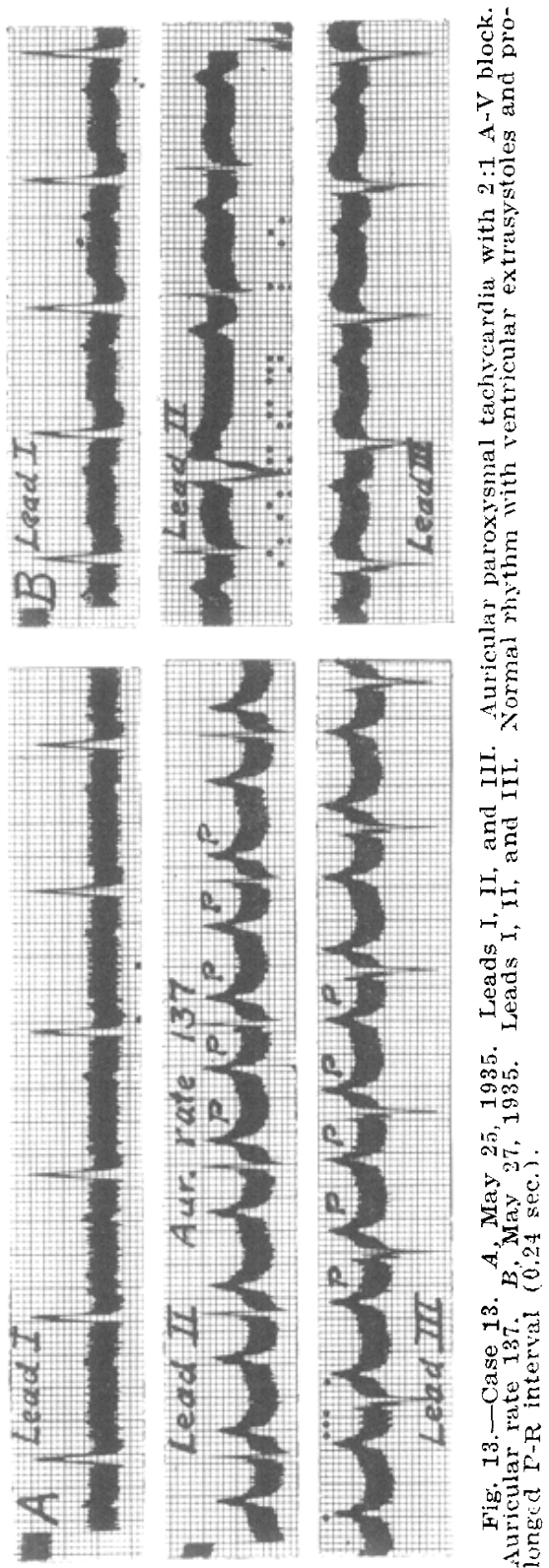

Digitalis, in a dose of $0.5 \mathrm{Gm}$., was given November 9 . On the following day the electrocardiogram (Fig. 12, A) showed auricular paroxysmal tachycardia with partial A-V block, usually $4: 1$, with an auricular rate of 21.5 and a ventricular rate of 55 per minute. On November 11 the tracing (Fig. 12, B) showed auricular fibrillation with a ventricular rate of 60 . There were many idioventricular beats, indicating overdigitalization. Subsequently the patient had a transurethral resection of the prostate, from which lie made a good recovery. 
(ASF L:-A white man, 68 yours of age, was examined May 24, 1935. Jle hal heen troubled with attacks of nausea and vomiting. Examination showed that the heart was of normal size, but irrogular, with a rate of os per minute. The lungs were normal, and the abdomen whs negative. There was no elema. An electro ardiogram on the following day (Fig. 1\%, 1) showed auricular paroxysmal tany cardia with $2: 1 \mathrm{~A}-\mathrm{V}$ block. The auricular rate was 137 , and the ventricular rate; 68 , per minute. There were a few rentricular extrasystoles. On May 27 the rhythim was normal except for ventricular extrasystoles (Fig. 13. B). A few months later the patient developed cardiac failure, hut the cardiue rhythin remainel normal.

CASk 14.-A white woman, 17 years of age, was almitted Tov. 1, 1932. She gave a history of nervousness, weakness, fatigue, palpitation, and irregularity of the heart. These symptoms began in August, 1931, and improved temporarily under iodine therapy in January, 1930. Fnlargement of the thyroid gland appeared at that time. The palpitation was deseribed as forceful heating of the heart, and the irregularity as a skipping of beats. No attacks or parnysus of tachycardia or irregularity were notirel.
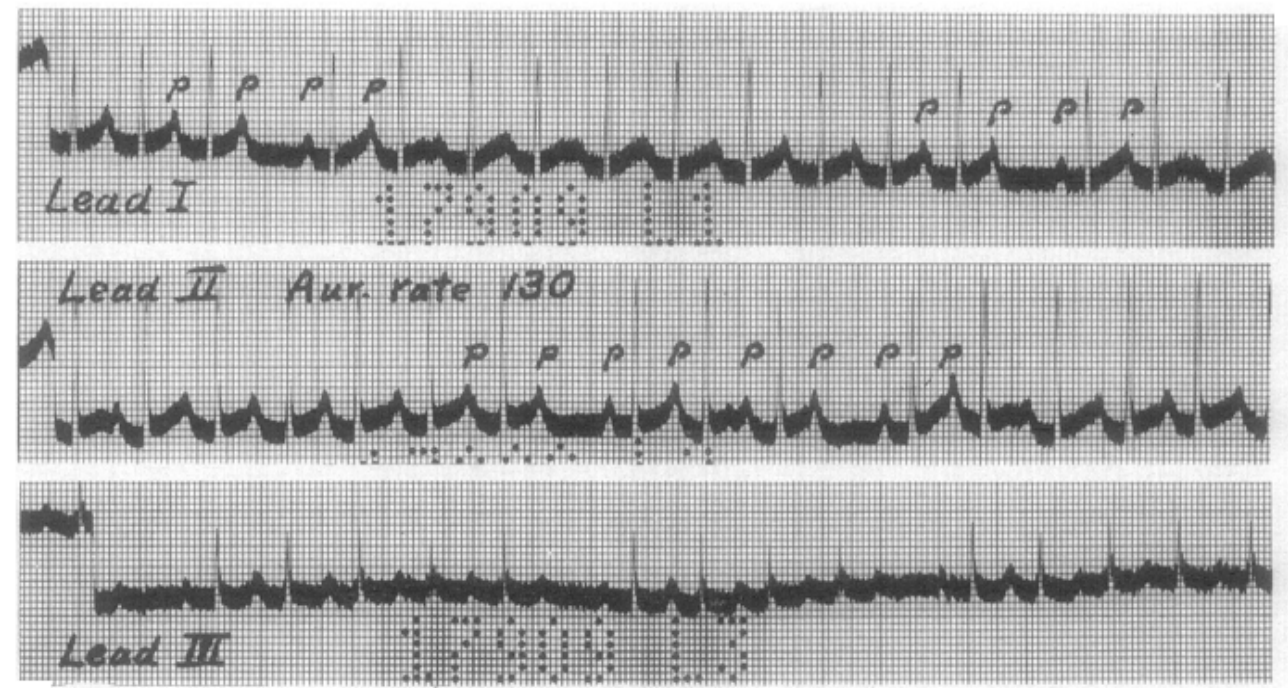

Fig. 14.-Case 14. Leads I.'II, and III. Probably auricular paroxysmal tachycardia and partial $A-V$ block with dropped beats. Auricular rate, 130 .

Examination showed moderate enlargement of the thyroid, with a bruit over the gland. There were exophthalmos and a fine tremor of the fingers. The heart was normal in size, and there seemed to be numerous llropped beats. The rate was 108. There were no murmurs. The blood pressure was $135 / 78$. There were no signs of congestive failure. The basal metabolic rate was plus 45 per cent. Roentgenologic examination showed no abnormality of the heart. The electrocardiogram (Fig. 14) showed an auricular rate of 130 and partial A-V block, with frequent dropped beats. Subsequently the rhythm seemed normal clinically, but no other electrocardiograms were laken. A subtotal thyroidectomy was followed by a good recovery. It is possible that this patient had auricular paroxysmal tachycardia with partial $A-V$ block, but this is not certain.

Case 15.-A white man, 64 years of age, was admitted Jan. 18, 1933. For four months he had suffered from attacks of rapid beating of the heart and shortness of breath; these lasted a few minutes and occurred several times a day. Exami- 
nation showed that the patient was overweight. The heart was moderately enlarged, and there were faint systolic-murmurs at the apex and base. The rhythm was irregular, and the rate was approximately 200 per minute. The blood pressure was 120 , systolic. There were no signs of congestive cardiac failure. There were abrupt changes from tachycardia to normal rate, and from normal rate to tachycardia. The tachycardia was stopped by pressure upon the right carotid sinus, but soon returned. Many electrocardiograms were obtained, and showed a complicated arrhythmia. There were many brief attacks of tachycardia, apparently arising from two or more foci in the auricles, which had an abrupt onset and termination. There was also variation in the form of the ventricular deflections. In addition, there were brief periods of partial A-V block, as shown in Fig. 15. There were also premature ventricular defiections of abnormal outline, some of which probably were ventricular extrasystoles. Quinidine was given irregularly from January 21 to 24 without apparent benefit. Digitalization was begun on January 25 and completed on January 27 , and then maintained by $0.1 \mathrm{Gm}$. daily. After this there were occasional auricular extrasystoles (Fig. 15, D), but no further attacks of tachycardia or dyspnea.
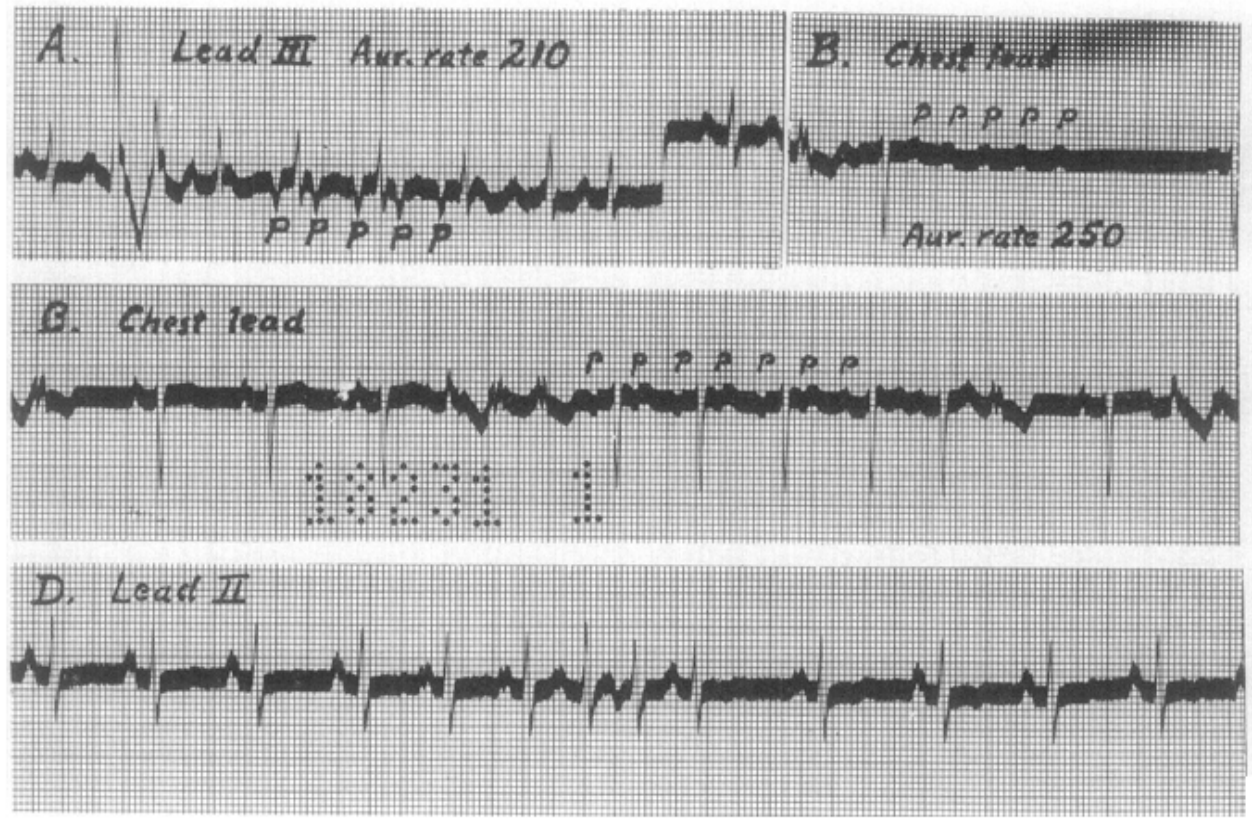

Fig. 15.-Case 15. A, Jan. 19, 1933. Lead III. A short paroxysm of tachycardia arising in at least two different foci in the auricles, and showing partial $A-V$ block. Auricular rate 210 . $B$, Jan. 21, 1933. Precordial lead. Unusual mode of termination of an attack; there is A-V block. Auricular rate 250. $C$. Tan. 21, 1933. Precordial lead. A short attack showing partial A-V block. Auricular rate approximately 200. D, Jan. 24, 1933. Lead II. Normal rhythm with auricular extrasystoles.

CASE 16.-A 26-year-old white woman entered the hospital March 13, 1929. For nearly a year she had suffered from shortness of breath, palpitation, swelling of the ankles, and nocturia. For the preceding month the swelling had been more extensive, involving the legs, thighs, and abdomen. There was no history of rheumatic fever.

Physical examination showed that the patient was dyspneic, orthopneic, and cyanotic. There was pronounced edema of both lower extremities, the right upper extremity, and the right breast. The heart was markedly enlarged. A systolic 
murmur and gallop rhythm were present at the apex. No diastolio murmur was leard. The rhythm was regular, and the rate was 132 per ninute. The bloon pressure was 170/12s. There were râles at the bases of the lungs. The liver and spleen were enlarged.

Roentgenologic examination showed marked cardiac enlargement and congestion of the lungs.

The electrocardiogram (Fig. 16, A) was taken March 16, 1929, after 1.8 Gm. of digitalis had been given. There was complete atrioventricular dissociation. The auricles and the ventricles were beating regularly and independently, the former at a rate of 160 and the latter at 84 per minute. No other eletrocardiograms were obtained during this admission. The patient improved rapidly. Diuresis was accompanied by a loss of weight from $2: 7$ to $1: 7$ pounds. The blood pressure fell to $140 / 100$, and the heart rate to 85 .

'Ilhe patient returned to the hospital .July 31, 1931. Her symptoms and physica] signs were essentially the same as on the previous armission. The blood pressure was $900 / 150$. The heart rate varied from 90 to 75 per minute, and the electrorardiogram ( $\mathrm{Fig}$. 16, $B$ ) showed normal rhythm. In this rurve the $P$ waves are of different ontline, as compared with the previous aurve. The patient again im. provert.
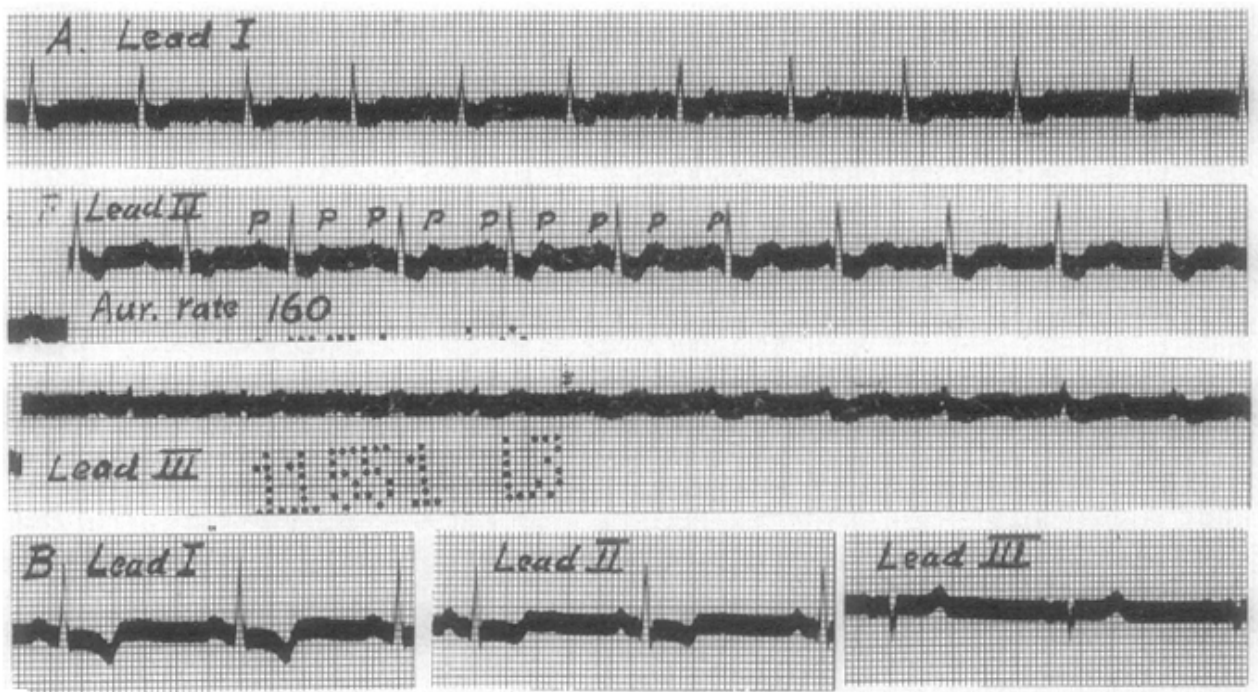

Fig. 16.-Case 16. A, March 16, 1929. Leads I, II, and III. Auricular paroxysmal tachycardia with complete dissociation. Auricular rate 1601, rentricular ratu, 84. $B$. Aug. 11, 1931. Jeads 1, Il, and III. Normal whythm.

Case 17.-A 45-year-old white man entered the hospital May 12, 1942. He had felt well until one year previously. At that time he developed severe dyspnea during molerate exertion. It was relieved by morphine. Tfis bloot pressure was found to be 220. After that his pressure remained high, and he had headaches, blurred vision, and attacks of paroxysmal noeturnal dyspnea. Two months prior to admission his blood pressure was 240 . A diagnosis of nyocardial infarction was made by his physician. Since then he had been at rest in bed, and had taken digitalis regularly. There was no history of pain in the shest or edema of the extremities.

Physical examination showed an obese man who was dyspneic, orthopneic, and slightly eyanotic. The eye grounds showed evidenee of retinal arteriosclerosis and 
angiospasm. The heart was enlarged and was beating regularly at a rate of 120 . The heart sounds were scarcely audible beause of many coarse bubbling râles in the lungs. The blood pressure was $290 / 150$. The peripheral vessels were not appreciably thickened. The liver was not enlarger. There was no edema of the extremities.

Shortly after admission, while being examined, the patient lad an attack of acute pulmonary edema, from which he revovered after the administration of theophylline intravenously, and morphine, and phlebotomy, with the removal of 500 ) c.e. of blood, and the use of the oxygen tent. Te was given $1.6 \mathrm{Gm}$. of digitalis in twelve hours, which causer nausta and vomiting. On the following day the patient was still somewhat ryspneic, ant the bloot pressure was 180/120. There was no pain in the chest. During the next few days the temperature rose to $99.6^{\circ}$ F., the leucocyte count rose from 10,000 to $14,0.40$ per $\because$ mm., and the latient

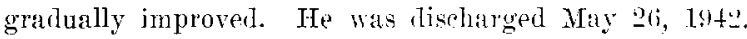
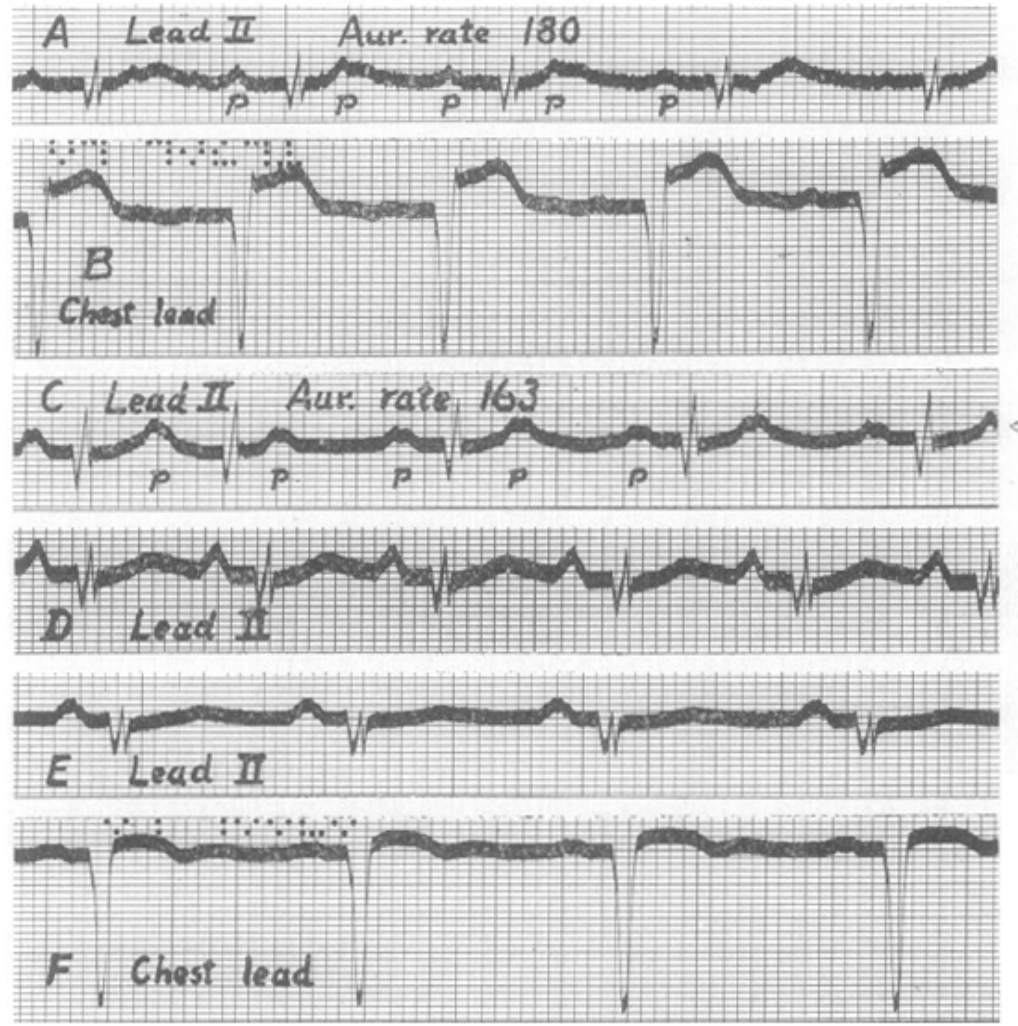

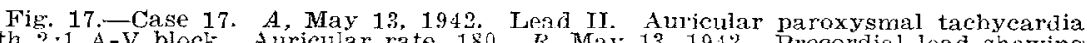
with $3: 1$ A-V block. Auricular rate. $180 . W$, Maj 13,1942 Precordial lead showing the changes of recent niyocardial infarction. $C$, May 15, 1942, 2:15 P.M. Lead II. Auricular paroxysmal tachycardia with partial A-V block, usually $2: 1$. Auricular rate 163. Note the change in the form of the $P$ waves, $D$, May 15, 1942, 4:50 P.M. I.ead T. Normal rhythm. F, May 20. 1942. Lead II. Normal rhythm. Note the change in the form of the $\mathrm{P}$ waves. $F$, May 20,1942 . Precordial lead showing the expected progression of the changes accompanying myocaldial infarction.

The first electrocardiograin (Fig. 17, $A$ ) was oltained May 1\%, 1912, the day after armission. It showel auricular paroxysmal tachycardia with $2: 1 \mathrm{~A}-\mathrm{V}$ block; the auricular rate was 180 . Precordial leads showed changes suggesting very recent myocardial infaretion (Fig. 17, B). On May 15, at 2:15 P.M. (Fig. 17, C), the auricular paroxysmal tarhycardia was still present, with $2: 1 \mathrm{~A} \cdot \mathrm{V}$ block most of tho 
time, and an auricular rate of 16.. The auricular deflections were somewhat different in form from those of the previous curve. At 4:50 P.M. of the same day, normal rhythm was present, and the rate was 107 (Fig. 17, D). On May 20, 1942 (Fig. 17, E), normal rhythm was still present; the auricular deflections were different in form from those of the previous curve, and the rate was slower. Precordial leads showed the expected jurogression of the changes of myocardial infarctiou (Fig. 17, F).

CAsE 18.-A white man, 45 years of age, was a patient in the hospital from July 5 to 15, 1940. Four years previously he had experienced sudden, severe pain beneath the sternum which persisted for four hours and was relieved by morphine. After that he was subject to substernal pain upon slight effort. For about nine months he had been dyspneic upon mild exertion and sometimes at rest. The breathing was often noisy. Cough lad been present for four montls. He was found to be allergic to louse dust and several other substances, and was given epinephrine by nebulizer and ephedrine by mouth. There har been no adema of the extremities. Examination showed slight cardiac enlargement, presystolic gallop rhythm, and many wheezing, musical, and crackling râles in the lungs. The bloot pressure was $130 / 94$. He was given rest and digitalis, and improverl remarkably.
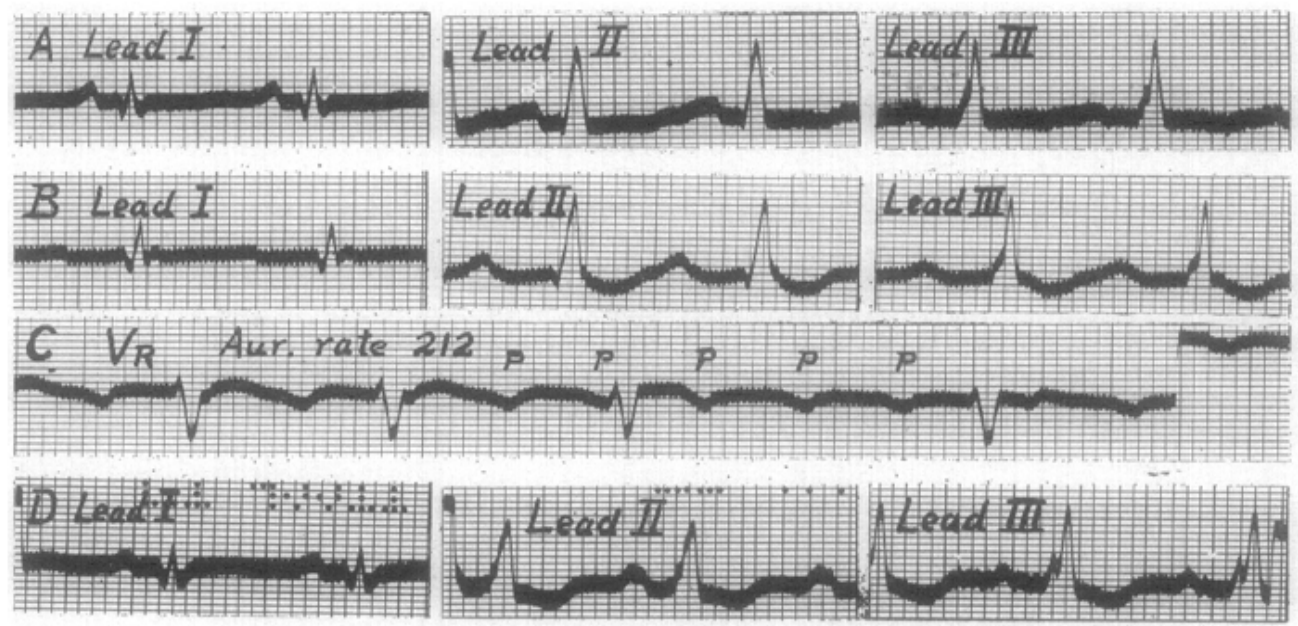

Fig. 18.-Case 18. A, July 6, 1940. Leads I, II and III. Normal rhythm. $B$, June 2,1943 . Leads I, It, and III. Auricular paroxysmal tachycardia with $2: 1$ A-V block. The auricular tachycardia is not readily apparent in these leads. $C$, June 2, 1942. Right arm potential (right arm electrode paired with the central terminal) the short periods of $3: 1 \mathrm{~A}-\mathrm{V}$ block. $D$, June 9,1942 . Leads I, II, and III. Normal rhy thrm.

After being free from symptoms for six months, he began having shortness of breath again. In October, 1911, the substernal pain recurred, and thereafter orthopnea and edema of the ankles developed. He continued taking digitalis regularly. On May 25, 1942, he had an attack of tachycardia which was abrupt in onset and termination, lasted one hour, and was accompanied by substernal pain. He returned to the hospital June 1, 1942. Examination showed a dyspneic, apprehensive man with a severe, nonproductive cough. There were many musical and crepitant râles in the lungs. The heart was slightly enlarged, and gallop rhythm was present. The blood pressure was $152 / 118$. There was slight edema of the ankles. 
On the second hospital day (June 2, 1942), lie devoloped tachycardia, acconpanied by substernal pain. The heart rate nas 160 ; it was slowed temporarily by pressure upon the left earotid sinus, but the tachycardia returned promptly upon cessation of the pressure. On June 4 the pulse was slower and the tachycardia had ceased after persisting for two days. There was, however, no other change in the patient's condition. He gradually improved.

The electrocardiagrams on the first admission showed changes suggestive of old myocardial infarction (Fig. 18, A). On June 2, 1942, the curve showed auricular paroxysmal tachycardia with an auricular rate of 212 and partial $A \cdot V$ block, usually $3: 1$, sometimes $3: 1$ (Fig. $18, B$ and $C$ ). Normal rhythm was present on June 4 and persisted (Fig. 18,D).

\section{COMMENT}

Clinical Features.-Our interest in auricular paroxysmal tachycardia with $A-V$ block was aroused by seeing 7 patients with this disturbance in the brief period of ten months, from October, 1937, to August, 1938. A review of 100 unselected cases of auricular paroxysmal tachycardia revealed 8 additional cases in which there was $A-V$ block. The essential data in one additional case were supplied by Dr. John Parkinson (Case 1). The last 2 cases are of interest because of the associated myocardial infarction. In 8 of these 18 cases the tachycardia was the outstanding symptom, and in 5 it caused moderate to marked disability. In 4 other cases the tachycardia, although not the chief difficulty, was of importance in that it contributed to the disability of the patients. In the remaining 6 cases there was no disability, or the abnormal rhythm was merely an incident in the course of other more important conditions.

The degree of disability experienced by these patients is often greater than that which occurs with the common type of auricular paroxysmal tachycardia. In 29 cases it was possible to estimate the degree of disability. It was marked in 10 , moderate in 7 , and slight in 6 . There was no apparent disability in 2, and in 4 others the abnormal rhythm was merely an incident of relatively minor importance in the course of some other illness. In general, the patients with organic heart disease and those with attacks of longer duration suffered more pronounced disability than the others (see 'Table I). Two patients developed acute edema of the lungs; both of these had organic heart disease. Another patient without organic heart disease died of cardiac failure caused by paroxysmal tachycardia which had been present almost continuously for three months.

In auricular paroxysmal tachycardia with $A-V$ block, the duration of the attacks is often longer than in the common type of auricular paroxysmal tachycardia. Of the 17 previously reported cases, in 8 the attacks lasted several days; the longest was ninety-four days. Of our 18 patients, 13 had attacks lasting two days or longer. Three of these are known to have had attacks lasting twenty-six, sixty, and thirteen days, respectively. On the other hand, in 3 of the previous cases and in 3 of our own there were brief attacks which lasted only a few minutes.

The auricular rate is usually between 165 and 200 per minute. 
Faster and stower lates sometimes werur. Four pationts shened, al times, rates of 121, 120, 120, and 12!9 per minute, respertively. In unn of these (Case 15) the slowing was caused be digitalis, and in another (Case 17) by assuming the recumbent posture, whous in our (ause $t$ it was attributed to quinidine. Three of our other patients showed auricular rates of 136,137 , and 130 per minute, respectively, and in one of these the slowing was caused by quinidine (Case 6). Fery rapid anteular rates are sometimes eneountered. Lewis' patient ${ }^{1}$ had a rate of 290 per minute. The first of the patients of Spragae and White showed a rate of 270 upon one occasion. Two of onr patients hat, at times, rates of 235 and 250 per minute, respetively. In some cases the auriertlar rate shows rather pronouned variations, usnally in response to drugs.

The onset and fermination of the abnormal aurienlar activity have been recorded graphically in several instanecs. They were abrupt, just as in paroxysmal tachycardia without $\mathrm{L}-\mathrm{V}$ block. The case reported by Maddox ${ }^{11}$ js exceptional in that the attack of tanchyodia terminated hy gradual slowing of the rate orer a period of sereral days. In this and in many other respects it resembled that reported by Field, Barker, and Alexander. ${ }^{15}$

As a rule there is an abrupt tansition from nomal rhythm to paroxysnal tachyeardia at the onset, and from paroxymal lachyeardia to normal rhythm at the fermination of the attacks. In Dock's casce, after $5 \mathrm{Gm}$. of digitalis in sixten dars, the mechanism changed to atrioventricular bradyeardia with reciplocating rhythm. In Brown's patient, ${ }^{10}$ after large amounts of digitalis, the mechanism ehanged from auricular paroxymal tarhyeardia to anricular fibrillation, and then to normal rhythm. One of our patients (case 10 ) had anrieular paroxysmal tachycardia with $\mathrm{A}-\mathrm{V}$ hock at a $1 \mathrm{ime}$ when he was overdigitalized. Shortly atter the digitalis was stopped the mechanism rhanged to auricular fibrillation. and then 10 normal rhythm (Fig. 10). Another patient (Case 12) was likewise overdigitalized when the paroxysmal tachyeardia was present. On the following day the rhythm changed to andicular fibrillation, which persisted flig. 12: Nhlongh the transitions were not recorded, it seems highly probable that in these?

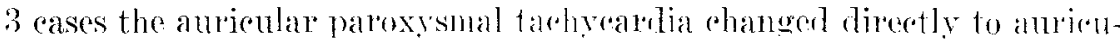
lar fibrillation without intervening normal rhythm. Spontancous transitions from paroxysmal tachycardia to aurieulat fluter or fibrillation have been recorded, as have r.hanges from flutter or fibrillation w paroxysmal tachycardia. Parkinson and Mathias ${ }^{16}$ ohserved a patient with auricular paroxysmal tachyeardia whose rato increased progressively until there was a gradual transition to auricular flutter. Records were obtained by Carr ${ }^{17}$ on a patient with many short paroxysms of tachycardia arising in the $A-V$ node who showed auricular flutter for a few seconds at the onset and temination of the attacks. This patient had received moderate amounts of rigitalis. Lewis ${ }^{18}$ has reported a case 
in which auricular fibrillation apparently changed to auricular paroxysmal tachycardia; the record of the transition was not published. It is possible that digitalis was responsible for the change to anricular fibrillation in the cases mentioned above, although in other cases of auricular paroxysmal tachycardia digitalis has restored normal rhythm without intervening auricular flutter of fibrillation.

In our Case 2 auricular flutter and auricular fibrillation were observed at different times, but it is not known whether there were transitions from either of these abnormal rhythms to paroxysmal tachycardia or vice versa. It is of interest that, of 100 unselected cases of auricular paroxysmal tachycardia, in only 5 was the patient known to have had auricular flutter or fibrillation, and that 3 of these had partial $\mathrm{A}-\mathrm{V}$ block.

In some of the cases in which the onset or termination of an attack was recorded there was $1: 1$ ventricular response; the $A-V$ block appeared during the course of the paroxysm. In other instances the block was present at the very beginning of the attack or continued to its very end.

In most cases the A-V block was fairly persistent or was maintained by digitalis, but 1:1 response could be brought on by exertion or occurred when digitalis was not taken. In some instances the patient was aware of the abnormal cardiae mechanism only during the periods of 1:1 ventricular response, which began and ended suddenly. The occurrence of $1: 1$ response increased the severity of the symptoms and accounted for the disability of some of the patients. Others, however, were incapacitated even with ventricular rates of about 100 per mimute. In a few cases the block was transient and of short duration.

Patients with aurieular paroxysmal tachyeardia and partial $\mathrm{A}-\mathrm{V}$ block are often very resistant to treatment. This is reflected in the long duration of some of the atlacks. Pressure upon the carotid sinus: restored normal rhythm only in Case 12 (Mackinnon). In many other cases it failed to do so. It commonly increased the degree of block and slowed the ventricles temporarily.

Digitalis was beneficial in 7 of the 17 previously reported cases: normal rhythm returned soon after the administration of full doses. In Cases 11 and 15 it was given without henefit, and, in the other 8 cases, it was apparently not used. Digitalis was given in 16 of our 18 cases, and in only 7 did it appear beneficial. In only 4 of these did normal rhythm return soon after the administration of the drug. In the other 3 it increased the degree of $\mathrm{A}-\mathrm{V}$ block and prevented, in part, the oceurrence of 1:1 response, so that the patients were improved symptomatically, but normal rhythm returned several days or wecks after full digitalization, and could not be attributed definitely to the drug. In some of the other cases digitalis may have been at least partly responsible for the partial $\Lambda-V$ block, but did not appear to be beneficial in other respects. Digitalis sometimes eauses considerable slowing of the auricular rate (Cases 4 and 14). 
Quinidine was given in 5 of the previously reported cases. It prevented the attacks of paroxysmal tachycardia in Case 17 (Fine and Miller), but was without value in Cases 5, 6, 7 , and 15. Quinine likewise was given in 5 of the previously reported eases. It restored normal rhythm in 3 (Cases 2, 8, and 10), hut was without benefit in Cases 4 and 15. Quinidine was given to 8 of our patients. It restored normal rhythm in Cases 6,7 , and 9 . In Cases 6 and 7. its continued use definitely prevented the return of the tachycardia, and in Case 9 it was probably of some benefit in preventing recurrences. In Cases 1, 2, 3, 4, and 15, quinidine was given without apparent benefit, although it slowed the auricular rate in Cases 3 and 4 . There was no allequate explanation for death in Case 6 ; the patient had been taking quinidine sulfate in a dose of $0.3 \mathrm{Gm} .3$ times daily for several days, but it is scarcely possible that this could have been responsible. Quinine was used in Case 2 without apparent benefit. Both quinidine and quinine sometimes cause conspicuous slowing of the auricular rate (Case 4 and our Cases 3,4 , and 6 ).

Mecholyl was given to 3 of our patients. It caused transient slowing of the ventricles by increasing the degree of block, but did not restore normal rhythm.

Electrocardiograms.-In the common type of auricular paroxysmal tachycardia the $\mathrm{P}$ waves are often almost indistinguishable because they are very small or flat, or because, in addition to being small, they fall upon some part of the ventricular complex. In about one-sixth of the cases the $\mathrm{P}$ waves are inverted. In only about 30 per cent are they upright and approximately similar in form to the $\mathrm{P}$ waves of normal rhythm. In auricular paroxysmal tachycardia with A-V block, about 60 per cent of the patients have $P$ waves which are upright or largely so, and resemble, perhaps not exactly, but at least fairly closely, the $P$ waves of normal rhythm. When $\mathrm{P}$ is diphasic or notched, it often shows a similar configuration during normal rhythm. The similarity of the $\mathrm{P}$ waves during the tachycardia and during normal rhythm is shown in 6 of the previously reported cases (Cases 3, 6, 7, 8, 9, and 15), and is well illustrated in ten cases of the present series (Cases 1, 2, 3, 5, $7,10,11,13,16$, and 18). This indicates that in these cases the paroxysmal tachycardia had its origin near the sinoauricular node. It is possible that $\mathrm{A}-\mathrm{V}$ block is more likely to occur in such cases, as compared with eases in which the form of $\mathrm{P}$ suggests an origin near the auriculoventricular node. In Cases 12 and 14 the $\mathrm{P}$ waves were upright during the tachycardia, but no tracings of normal rhythm were obtained for comparison. In 6 of the previously reported calses (Cases 2, 4, 5, 11, 14, and 17) and in 6 cases of our series (Cases 4, 6, 8, 9, 15, and 17 ) the $P$ waves during the tachycardia were quite different from the $P$ waves of normal rhythm. In Cases 4 and $8, P$ was very small during the tachycardia, whereas, in Cases 6 and 15, it was inverted. In Cases 9 and 17 , the $\mathbf{P}$ waves were upright during the tachycardia but quite different in form from those of normal rhythm. 
When the $P$ waves are small or indistinct in the standard leads, it may not be possible to identify them with certainty, or to ascertain what type of arrhythmia is present. Under such circumstances it may be helpful to employ chest leads. By leading from two precordial contacts, one over the upper part of the sternum and the other over the ensiform, it is usually possible to record large auricular waves which are readily identified. This is well illustrated in Case 4 (Fig. 4). Esophageal leads may be even more helpful, for they invariably yield very large auricular deflections when employed as described by Brown. ${ }^{10}$ They may be especially helpful in distinguishing auricular paroxysmal tachycardia from flutter. In the former the auricular deflections are separated, during A-V block, by periods of electrical quiescence, in which the curve is at rest on the base line, whereas, in the latter, the curve is never at rest, but shows continuous changes in electrical potential (Figs. 2 and 7 ). These observations confirm those of Brown. The use of esophageal leads, however, imposes some hardship upon the patient.

The partial A-V block seems to be caused by the abnormally high auricular rate, at least to a considerable degree. In some of the patients, digitalis was a contributing factor. In none of the previously reported cases was there abnormal prolongation of the P-R interval during normal rhythm, although in several it was 0.20 second. In Case 2 (Singer and Winterberg), complete block persisted after the termination of the paroxysmal tachyeardia. In the present series, likewise, the P-R interval was nearly always normal during normal rhythm, but there were a few exceptions. In Case 4 it was 0.22 second at times, but large amounts of digitalis had been given. In Case 10 the P-R interval was 0.20 second several months before the tachycardia occurred and before digitalis was given; when normal rhythm returned after the paroxysmal tachycardia it was 0.28 second, but the patient had been overdigitalized. One patient (Case 13) had a P-R interval of 0.24 second on the day when normal rhythm returned, and he had received no drugs; four months later it was 0.19 second.

The oecurrence of anricular flutter and anrienlar fibrillation in Cases 2, 10, and 12 has been mentioned. Two other patients (Cases 7 and 8) showed abnormal auricular mechanism after cessation of the paroxysmal tachycardia; they yielded curves in which no auricular waves could be identified. It was thought that they might represent A-V nodal rhythm, but no special leads were employed and no large venous pulsations were observed, and it is possible that there was auricular standstill. The ventricles were beating regularly at normal rates. In several cases normal rhythm was disturbed by occasional auricular extrasystoles. One patient (Case 17) showed changes in the form of the $\mathrm{P}$ waves, both during the paroxysm of tachycardia and during normal rhythm shortly after the cessation of the attack. 
The Mechanism of Aurulur Paroxysmal Tachycardie-Auricular paroxysmal tachyeardia with partial $A-V$ block resembles aluricular flutter in many respects. It resembles flutter much more elosely than does the common type of anricular paroxysmal tachycardia. 'The similarities extend beyond the fresenee of the partial block and the relatively long duration of some of the attacks. Quinidine and quinine often slow the auricular rate in auricular paroxysulal tachyeardia and always do so in auricular fluther. In a fow cases, digitalis in large amounts apparently converted anrenlar paroxysmal tarhyoardia into aurieular fibrillation, a common orenrence in andulat flutter. In these ases, as in flutter, pressure upon the catrotid sinus temporarily increases the degree of hlock and slows the rentricles, but almost never stops the attacks of ahnomal rhythm. With respece to A-T hlock, the differences between anrienlar paroxysmal tachyoralia and auricular flutter may be caused ehiefly by the diffecenes in the anricular rates in the two conditions.

In spite ot the resemhlaneses heween auriedat paroxysmal tarehycardia with partial $A-Y$ block and auricular flutter, the two conditions differ from each other in sereal important resperts. Jigitalis sometimes slows the anroular late in the former, whoreas, in the latter, it has little effect, or induces anterular fibrillation. Pressure upon the "arotid simus restored normal rhythm in Case 13 (Mackinnon); it never: does so in aurienlar flutter. In the common type of paroxysmal tachyaratia, normal whythm is often restored by pressure upon the carotid sinus. An important differenoe between auricular paroxysmal tachyrardia with partial $A-T$ block and auricular fluter is that in the former the aurieular deflections are separated by periods of electrical quiescenee, during which the enre is at rest on tho base line, whereas, in the latter, the "urve is never al rest, but shuws continuous rhanges in electrical potential. This is apparent quite commonly in standard leads, usually in precordial loads, and always in esophageal loads.

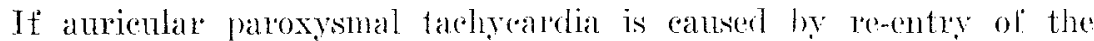
impulse, it must be a sperial kind of eireus rhythm, differing from that of auricular fibrilation. (Cirase rhythm involving as part of the path of the cirrulating excitation ware cither the sinoamieular nole

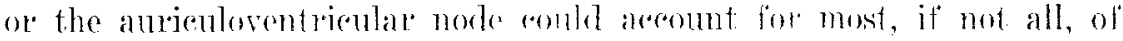
the features of alureular paroxymal tachycardia. This possibility has been discussed briefly by Ashman and Hull." In our opinion, eircus rhythm can aceount for aurieular paroxysmal tachyoudia only if it involves one of the nodes, or if the amount of muscle in some part of the main circus path is so small that its action potential cannot be recorded by ordinary methods. In a subsequent communication we hope to present additional evidenco hearing upon this problem, and to discuss it at greater length. 
SUMMARY

1. Seventeen previously reported cases of auricular paroxysmal tachycardia with auriculoventricular block are reviewed, and eighteen additional cases are reported.

2. This arrhythmia may oceur at almost any age, and in persons with otherwise normal hearts or with organic heart disease.

3. The attacks are often of long duration, i.e., they commonly last several days or longer.

4. High-grade disability is common in patients with organic heart disease, but sometimes occurs in those with otherwise normal hearts. One patient without significant organic heart disease died of cardiac exhaustion and failure attributable entirely to the long continued tachycardia.

5. In some cases the auricular deflections of the electrocardiogram are small or not readily apparent in limb leads. In such instances precordial or esophageal leads are especially valuable because they yield prominent auricular waves and thus permit the identification of the arrhythmia. Such curves are quite different from those of auricular flutter, in that the auricular deflections are separated by periods of electrical quiescence, with the curve at rest on the base line.

6. Digitalis in large amounts often restores normal rhythm. Quinidine and quinine are somewhat less effective, but sometimes restore normal rhythm, occasionally even when digitalis has failed to do so. Pressure upon the carotid sinus rarely terminates the paroxysms; it was suecessful in only one case (Mackinnon ${ }^{9}$. Mecholyl and acetyleho line have been ineffectual. Some patients may not respond to any of these measures; in one such instance normal rlythm returned spontaneously after a period of rest in bed, whereas, in another, death resulted from cardiae exhaustion caused by the prolonged tachyeardia.

7. Auricular paroxysmal tachycardia with partial A-V block resembles auricular flutter in many respects, but differs from it in some important particulars. Most of the features of auricular paroxysmal tachyeardia can be accounted for by circus rhythm involving either the sinoauricular node or the auriculoventricular node.

\section{REFTRWYCES}

1. Lewis, T.: The Mechanism and Graplic Registration of the Heart Beat, ed. 3, London, 1925, Shaw and Sons, Ltd.

2. Koplik, H.: Paroxysmal Tachycardia in Children, Am. T. M. Sc. 154: 834, 1917.

3. Singer, R., and Winterberg, H.: Chinin als Herz- und Gefäszmittel, Wien. Arch. f. inn. Mer. 3: 329, 1922.

4. Gallavardin, L.: Tachycardia Paroxystique a Forme Arythmique par Trouble de la Conductibilite Auriculo-Ventriculaire. Simulation d'un Rhythme Atrio. Ventriculaire, Arch. d. mal. du coeur 16: 117, 1923.

5. Lenhartz, H., and Samet, B.: Beitrag zur Kenntnis der Tachykardie, Wien. Arch. f. inn. Med. 9: $71,19 \Omega 4$.

6. Sprague, H. B., and White, P. D.: Heart-Block During Auricular Paroxysmal Tachycardia (Clinical Observations on Three Cases), M. Clin. North America 8: 1855, 1925. 
7. Wenckebach, K. F., and Winterberg, II.: Die unregelmiistige Iforztütigkeit, Leipzig, 1927, Wilhelm Engelmann.

8. Dock, W.: The Reciprocal Rhythm. Report of a Case in Which Auricular Tachycardia With Partial A-V Dissociation and Atrioventricular Bradycardia, With Reciprocating Rhythm, Were Present, Arch. Int. Med. 41: 745, 1928.

9. Mackinnon, A. V.: The Rhythm of Paroxysmal Tachycardia. An Electrocardiographic Study, Quart. J. Med. 27: 1, 1934.

10. Brown, W. H.: A Study of the Esophageal Lead in Clinical Flectrocardiography, AM. HEART J. 12; $307,1936$.

11. Maddox, K.: Auricular Paroxysmal Tarhycardia (Possibly Nomotopic) With Variable Auriculo-Ventrienlar Conduetion Time, AM. HeART J. 14: 183, 1937.

12. Maarss $\phi$, C.: Et tilfaelde af paroxysmatisk tachycardi med particlt atrioven trikulaert blok hos et 8 aars barn. Hospitalstid. 8: 1140, 1937.

13. Fine, M. J., and Miller, R.: Orthostatic Paroxysmal Auricular Tachycardia With Unusual Response to Change of Posture, AM. Heart .J. 20: 366, 1940.

14. Katz, L. N.: Electrocardiography, Philadelphia, 1941, lea and Febiger.

15. Field, H., Jr., Barker, P. S., ani Alexander, J.: Unusual Sinus Tachycardia With Observations on Vagal Activity, AM. HEART J. 9: 298, 1934.

16. Parkinson, John, and Mathias, H. H.: Tachycardia of Auricular Origin and Flutter With Phasic Variation in Auricular Rate and in Conduction, Heart 6: 27,1915 .

17. Carr, F. B.: Auriculoventricular Nodal Paroxysmal Iacleycardia and Auricular Flutter. Cake Report, AM. IIEarT J. 7: $668,1932$.

18. Lewis, T.: Auricular Fibrillation and Its Relationshin to Clinical Irregularity of the Heart, Heart 1: 306,1910 .

14. Ashman, R., and Hull, E.: Fscentials of Electrocariliography, ed. 2, New York, 1941, The Maemillan (o. 